\title{
Peripheral Mechanisms II: The Pharmacology of Peripherally Active Antitussive Drugs
}

\author{
D. Spina, I. McFadzean, F.K.R. Bertram, and C.P. Page( $\varangle)$
}

\section{Contents}

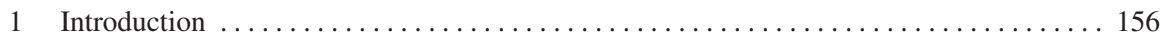

2 Mechanisms of Hypertussive States . . . . . . . . . . . . . . . . . . . . . 157

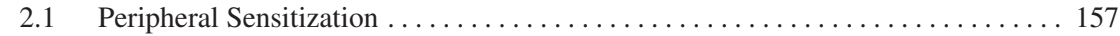

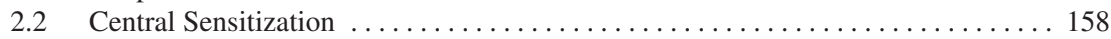

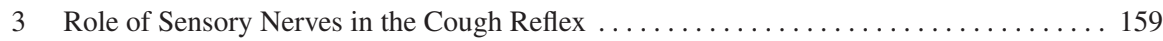

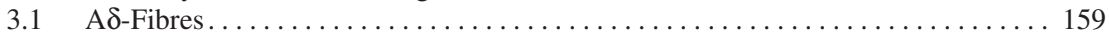

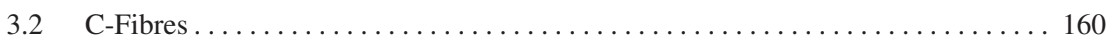

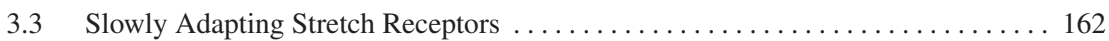

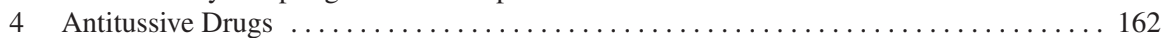

4.1 Sodium Channel Blockers ................................. 162

4.2 Tachykinin Receptor Antagonists .............................. 164

$4.3 \quad$ NOP Receptor Agonists . . . . . . . . . . . . . . . . . . . . . . . . . . . . . . 165

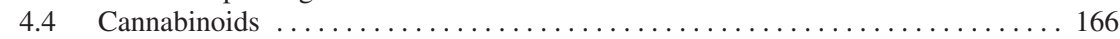

4.5 Drugs Targeting Transient Receptor Potential Channels ................ 167

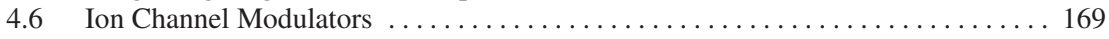

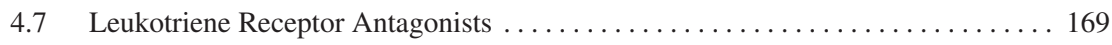

4.8 Bradykinin Antagonists . . . . . . . . . . . . . . . . . . . . . . 170

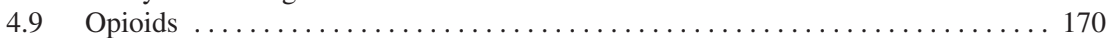

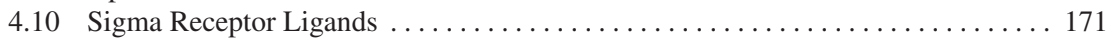

4.11 GABA Receptor Ligands . . . . . . . . . . . . . . . . . . . . . . . . 171

5 Challenges to the Development of Novel Antitussive Drugs $\ldots \ldots \ldots \ldots \ldots \ldots \ldots \ldots$. . . . 172

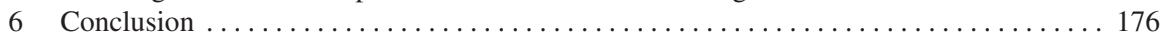

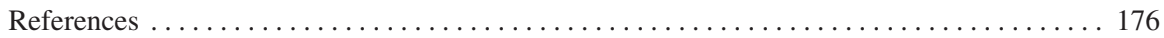

\begin{abstract}
Cough is an indispensable defensive reflex. Although generally beneficial, it is also a common symptom of diseases such as asthma, chronic obstructive pulmonary disease, upper respiratory tract infections, idiopathic pulmonary fibrosis and lung cancer. Cough remains a major unmet medical need and although the centrally acting opioids have remained the antitussive of choice for decades, they have
\end{abstract}

\section{C.P. Page}

Sackler Institute of Pulmonary Pharmacology, Division of Pharmaceutical Sciences, School of Biomedical and Health Sciences, King's College, London SE1 1UL, UK clive.page@kcl.ac.uk

K.F. Chung, J.G. Widdicombe (eds.), Pharmacology and Therapeutics of Cough,

(c) Springer-Verlag Berlin Heidelberg 2009 
many unwanted side effects. However, new research into the behaviour of airway sensory nerves has provided greater insight into the mechanisms of cough and new avenues for the discovery of novel non-opioid antitussive drugs. In this review, the pathophysiological mechanisms of cough and the development of novel antitussive drugs are reviewed.

\section{Introduction}

Cough is a reflex mechanism protecting the airways by ejecting obstructive or harmful substances. The afferent component of the reflex involves vagal sensory nerves with bodies in the jugular or nodose ganglia and terminals within the airway wall, activated by a combination of chemical and/or mechanical stimuli. Up to five subtypes of sensory airway afferents have been characterized (Canning 2006), all synapsing in the nucleus tractus solitarius (nTS) of the brainstem, from where second-order neurones project to the medullary respiratory pattern generator to initiate cough. Whilst acute cough (lasting a few weeks) is not a serious clinical problem, it is the most common respiratory ailment for which patients seek medical help and around $\$ 1$ billion is spent per annum in the USA on cough remedies (McGarvey and Morice 2006). Chronic cough (persisting for more than 8 weeks) is a serious debilitating condition estimated to affect some $14 \%$ of the population (Cullinan 1992). It can be a symptom of both pulmonary conditions, such as asthma (Dicpinigaitis 2006b), chronic obstructive pulmonary disease (COPD) (Braman 2006), idiopathic pulmonary fibrosis (Hope-Gill et al. 2003), upper-airway cough syndrome (postnasal drip) (Pratter 2006) and lung cancer (Kvale 2006), and extrapulmonary conditions, such as gastro-oesophageal reflux (Irwin 2006). It has an adverse effect on quality of life, being associated with complications ranging from frequent retching through incontinence and insomnia to social embarrassment (French et al. 1998, 2004, 2005). Treatment of the underlying disease often resolves chronic cough (Morice et al. 2004; Pratter et al. 2006), but this can take several months, during which time effective antitussive treatment would be desirable. Furthermore, there remains a significant cohort ( $\sim 40 \%$ of patients) (O'Connell et al. 1994) in which either the underlying cause is known but is irreversible or there is no identifiable underlying cause. In these individuals, relief from chronic cough depends upon effective antitussive drug treatment. Available drugs are of either limited effectiveness (Schroeder and Fahey 2002, 2004) or have problematic side effects and consequently there is a pressing need for safer, more effective agents (Dicpinigaitis 2004; Morice and Geppetti 2004; Reynolds et al. 2004).

Current antitussives are broadly divided according to their site of action as either central or peripheral, although many act to some extent at both locations. Centrally acting antitussives act within the central nervous system (CNS) to suppress central cough pathways and comprise the majority of currently used drugs. However, opioids, which are gold standard antitussive agents, suffer from numerous 
unwanted side effects, including sedation, constipation and drug dependence. There is therefore a clear and unmet need for the development of novel drugs which target airway afferent nerves directly and/or that target the processes that give rise to central sensitization of the cough reflex, possibly at the level of the nTS.

\section{Mechanisms of Hypertussive States}

In chronic, hypertussive cough states, normally innocuous stimuli that would not normally initiate a response, evoke cough (Bonham et al. 2004). There are clear parallels here with alterations during chronic pain states, characterized by hyperalgesia and allodynia. The mechanisms underlying such alterations have been well studied (Ji and Woolf 2001; Melzack et al. 2001; Woolf and Salter 2000) and can be subdivided into 'peripheral' and 'central' sensitization.

\subsection{Peripheral Sensitization}

Peripheral sensitization involves hyperexcitability of sensory neurones due to, for example, changes in voltage-gated sodium channel properties (Lai et al. 2004). Under inflammatory or disease conditions, many pathological changes can occur around and within sensory nerve fibres, leading to increased excitability as well as phenotypic changes in receptor and neurotransmitter expression. For instance, airway mechanosensitive A $\delta$-fibres do not contain neuropeptides under physiological conditions, but following viral and/or allergen challenge begin to synthesize neuropeptides (Carr et al. 2002; Myers et al. 2002). In addition, the excitability of airway A $\delta$-fibres and nTS neurones can be increased by antigen stimulation of the lungs of sensitized animals (Chen et al. 2001; Undem et al. 2002). Similarly, chronic exposure of guinea pigs to sidestream tobacco smoke augments pulmonary C-fibre responses to capsaicin and to lung hyperinflation (Mutoh et al. 1999, 2000). In addition, allergic airway inflammation has been reported to increase neuropeptide expression (substance $\mathrm{P}$, neurokinin A and calcitonin gene related peptide, CGRP) in sensory neurones originating in the guinea pig airway (Fischer and Hoffmann 1996; Myers et al. 2002). Together, these experimental studies suggested that sensory nerve plasticity can occur during inflammatory insults to the lung.

This view is also supported by clinical studies which have reported an increase in the number of TRPV1 immunopositive neurones (Groneberg et al. 2004) and the density of neuropeptide immunoreactive nerves (Lee et al. 2003; O'Connell et al. 1995) in the airways of individuals with chronic cough syndromes. This plasticity of the sensory neurones mediating cough provides a plausible mechanism leading to the hypertussive state, or 'sensitization'. The mechanisms contributing to the sensitization of airway nerves may be a more rational target for antitussive drug development rather than the 'hard-wired' cough reflex since it is generally 
accepted that inhibition of cough per se is probably of limited clinical benefit as this protective mechanism is of critical importance for clearing unwanted airway secretions.

\subsection{Central Sensitization}

In pain pathways, central sensitization involves enhanced efficiency of excitatory synaptic transmission pathways within the CNS, notably in the dorsal horn of the spinal cord at the synapse between the sensory nociceptor fibres and second-order relay neurones ( $\mathrm{Ji}$ et al. 2003). It has been suggested that central sensitization in the cough reflex loop might also underlie hypertussive states (Bonham et al. 2004, 2006a, b), but to date, there are few data confirming this.

In the spinal cord, central sensitization manifests itself as increased postsynaptic excitability of second-order relay neurones following a period of high-intensity stimulation of nociceptor afferents (Melzack et al. 2001; Woolf and Salter 2000). The relay neurones normally have a high threshold, responding only to the highintensity stimulation associated with the 'pain' response (Woolf and King 1989). Following central sensitization, the threshold is lowered such that normally innocuous stimuli now activate the relay neurones (Cook et al. 1987; Woolf and King 1990; Woolf and Wall 1986). The primary neurotransmitter at the synapse is glutamate, acting postsynaptically on both ionotropic ( $N$-methyl-D-aspartate, NMDA; and $\alpha$-amino-3-hydroxy-5-methyl-4-isoxazolepropionate, AMPA) receptors and metabotropic receptors (Andresen and Yang 1995; Chen et al. 1999; Drewe et al. 1990; Fortin and Champagnat 1993; Mifflin and Felder 1990; Smith et al. 1998; Wang and Bradley 1995), whilst $\gamma$-aminobutyric acid (GABA) acting on both $\mathrm{GABA}_{\mathrm{A}}$ and $\mathrm{GABA}_{\mathrm{B}}$ receptors mediates inhibitory synaptic responses (Brooks et al. 1992; Smith et al. 1998; Wang and Bradley 1995). There is also evidence that substance $P$ is released (Colin et al. 2002; Duggan et al. 1990) and acts on neurokinin $1\left(\mathrm{NK}_{1}\right)$ receptors to cause postsynaptic excitation and presynaptic modulation of glutamate and GABA release (Bailey et al. 2004; Sekizawa et al. 2003) thereby modulating the responsiveness of the postsynaptic cells.

Several mechanisms have been reported to contribute to the increase in synaptic efficacy (Ji et al. 2003; Ji and Woolf 2001; Malcangio and Lessmann 2003; Park and Vasko 2005). Relatively low frequency ( $\sim 5 \mathrm{~Hz})$ stimulation of nociceptors can cause 'windup' whereby successive stimuli cause increasing degrees of postsynaptic depolarization owing to removal of the voltage-dependent magnesium block of NMDA receptors. Windup is short-lived, dissipating on removal of the synaptic input, but the calcium entry associated with NMDA receptor activation, allied to that through voltage-gated channels, activates intracellular signalling cascades that lead to longer-lasting changes in the expression and function of receptors and ion channels (Caudle et al. 2005; Gao et al. 2005; Guo et al. 2002; Ji et al. 1999; Pezet et al. 2005; Suzuki et al. 2005; Yang et al. 2004; Zou et al. 2000).

There is good evidence to suggest that a similar scenario might operate in the nTS following stimulation of airway afferent nerves during an inflammatory insult 
to the airways. Insults that can induce a hypertussive state produce changes in the presynaptic inputs to the nTS, but whether they also produce postsynaptic changes indicative of central sensitization is less clear. This view is supported by various experimental findings. The increased $\mathrm{C}$-fibre responsiveness to capsaicin in guinea pigs exposed to tobacco smoke is paralleled by increased firing of nTS relay neurones (Bonham et al. 2001; Mutoh et al. 2000); extended allergen exposure and episodic exposure to ozone can also cause an increase in excitability of primate nTS neurones (Chen et al. 2001, 2003). Furthermore, the intracerebroventricular administration of neurokinin antagonists inhibited the ability of airway $\mathrm{C}$-fibre stimulation to increase the sensitivity of the cough response to mechanical irritation of the airway mucosa (Mazzone et al. 2005). The release of sensory neuropeptides centrally into the brainstem might facilitate synaptic input from mechanosensitive afferent nerves in the lung that are involved in cough.

Clearly many sensory afferent fibre types contribute to or modulate the cough reflex. The integration of their signals occurs at the level of the nTS, found in the dorsal medulla. Here, both pulmonary and extrapulmonary (from other vagally innervated organs) afferent fibres terminate and provide polysynaptic input to secondorder neurones (Jordan 2001). Although subject to substantial cortical control, these second-order neurones likely alter the activity of the respiratory neurones typically responsible for normal breathing to produce cough (Pantaleo et al. 2002). Each of the synapses in this 'cough centre' is a potential pharmacological target for centrally acting antitussives.

\section{Role of Sensory Nerves in the Cough Reflex}

The cough reflex is known to include a 'hard-wiring' circuit as recently proposed (Canning et al. 2004; Canning 2006). The stimuli initiating the cough reflex stimulate sensory nerve fibres that have been broadly divided in to three main groups: A $\delta$-fibres, $\mathrm{C}$-fibres and slowly adapting stretch receptors (SARs). These fibres have been differentiated on the basis of their neurochemistry, anatomical location, conduction velocity, physiochemical sensitivity and adaptation to lung inflation (Canning et al. 2004; Canning 2006; Reynolds et al. 2004).

\subsection{A $\delta$-Fibres}

Rapidly adapting receptors (RARs) are thought to terminate within or slightly beneath the epithelium throughout the intrapulmonary airways and respond to changes in airway mechanics to regulate normal breathing (Widdicombe 2003). These fibres are sensitive to most tussive stimuli and it is likely their stimulation is of primary importance in the elicitation of the cough reflex (Widdicombe 2003). In general, their activity is increased by mechanical stimuli such as mucus secretion 
or oedema, but they are insensitive to many chemical stimuli that provoke cough, including bradykinin and capsaicin (Lee et al. 2001). However, in the guinea pig at least, the variability in mechanical and chemical sensitivities of A $\delta$-fibres is sufficient to believe there may be as many as three subdivisions: RAR-like, nociceptive and polymodal A $\delta$-fibres (Mazzone 2005).

The RAR-like A $\delta$-fibres are very responsive to mechanical stimulation, unresponsive to direct chemical stimuli like bradykinin and capsaicin, and have their cell bodies in the nodose ganglia (Hunter and Undem 1999; Riccio et al. 1996). By comparison, nociceptive $\mathrm{A} \delta$-fibres are sensitive to capsaicin and bradykinin, are 15 times less responsive to mechanical stimulation, have their cell bodies in the jugular ganglia and are mainly carried in the superior laryngeal nerve. The role of RARs as primary initiators of cough has been disputed following a number of observations (Mazzone and McGovern 2007). For example, cough sensitivity in healthy subjects is not altered by bronchoconstrictor agents which would be expected to activate RARs (Fujimura et al. 1996); exogenous administration of neuropeptides which would be anticipated to activate RARs indirectly owing to a combination of bronchoconstriction, mucus secretion and oedema was ineffective at evoking cough in healthy subjects, although cough to this stimulus is observed in patients with inflamed lungs (Hope-Gill et al. 2003; Sekizawa et al. 1996); and sensory nerve activation and, by extension, release of sensory neuropeptides failed to initiate cough following indirect activation of RAR's in anaesthetized guinea pigs (Canning et al. 2004; Mazzone et al. 2005). It seems likely that activation of RARs resulting in cough may be of greater relevance in disease. Nonetheless, these inconsistencies have led investigators to further probe the role of A $\delta$-fibres in cough.

Only recently have the polymodal A $\delta$-fibres been identified. These fibres are similar to RAR-like fibres in that they originate in the nodose ganglia, are activated by mechanical stimulation and acid but are unresponsive to capsaicin, bradykinin, smooth-muscle contraction or stretching of the airways. Interestingly, the conduction velocity of these polymodal $\mathrm{A} \delta$-fibres is much slower than the conduction velocity of RARs or SARs and is much faster than that of C-fibres. Furthermore, severing the recurrent laryngeal nerves which supply innervation to the trachea abolished cough in response to mechanical irritation of the tracheal mucosal surface in guinea pigs (Canning et al. 2004). It has been proposed that the primary function of these fibres is the elicitation of cough and as such they may be regarded as the 'hard-wiring' of the cough reflex (Canning et al. 2004; Mazzone et al. 2005).

\subsection{C-Fibres}

C-fibres play an important role in airway defensive reflexes. They respond to both mechanical (though with a higher threshold than A $\delta$-fibres) and chemical stimuli, including sulphur dioxide, capsaicin and bradykinin (Lee et al. 2001). In certain species they evoke the peripheral release of neuropeptides such as substance P, neurokinin A and CGRP via an axon reflex which leads to bronchoconstriction and 
neurogenic inflammation. Neuropeptide-dependent airway smooth-muscle contraction, oedema and mucus secretion can activate RARs. However, human airways contain very few substance P-containing nerve fibres and at present there is a lack of evidence indicating that these nerves correspond to the terminals of capsaicinsensitive C-fibres (Lundberg et al. 1984). Consistent with this observation, human airways from non-diseased individuals only contract modestly in response to capsaicin when compared with those of guinea pigs (Spina et al. 1998), although TRPV1-positive nerves have been described in the lung which do not contain sensory neuropeptides (Kagaya et al. 2002; Watanabe et al. 2005, 2006), suggesting that capsaicin-mediated effects may be able to occur independently of the release of neuropeptides. Similarly, TRPV1 receptors have been identified on A $\delta$ nociceptive fibres (Myers et al. 2002), which under normal physiological conditions do not synthesize neuropeptides, but can be activated by capsaicin. If these fibres were involved in the sensitization of the cough reflex, then this might explain the inability of neurokinin antagonists to modify cough clinically (Fahy et al. 1995). However, it is also likely that changes in C-fibre activity may occur in disease and hence these nerves would be anticipated to play a role in hypertussive states. Indeed, cough sensitivity to capsaicin is heightened in respiratory disease (Hope-Gill et al. 2003; Nakajima et al. 2006; O'Connell et al. 1996; Weinfeld et al. 2002) and the density of TRPV1- and neuropeptide-containing nerves is increased in chronic cough states (Groneberg et al. 2004; Lee et al. 2003; O'Connell et al. 1995).

A critical role for $\mathrm{C}$-fibres in cough has been proposed since this response can be induced by citric acid, capsaicin and bradykinin, all agents known to be stimulants of C-fibres in humans and animals (Karlsson 1996). In animal studies, chronic pretreatment with capsaicin to deplete $\mathrm{C}$-fibres of their sensory neuropeptides abolished cough as a response to citric acid in conscious animals, without affecting mechanically induced cough (Forsberg et al. 1988). It is plausible that high doses of capsaicin might also impair the function of a subpopulation of A $\delta$ nociceptive fibres which express TRPV1 (Myers et al. 2002) and therefore might have contributed to the functional impairment to cough in response to citric acid. Furthermore cough induced by capsaicin and citric acid was abolished when animals were pretreated with neurokinin antagonists (Bolser et al. 1997); whilst cough induced by capsaicin, cigarette smoke and bronchospasm in guinea pigs is inhibited with neurokinin antagonists (Yasumitsu et al. 1996) and by promoting degradation of endogenously released neuropeptides following treatment with neutral endopeptidase (Kohrogi et al. 1989), suggesting a role for neuropeptides in this cough response, at least in guinea pigs.

However, there is evidence to show that activation of C-fibres does not evoke cough. Anaesthetized animals failed to cough in response to capsaicin and bradykinin, yet the topical application of citric acid or mechanical irritation of the mucosal surface still evoked a cough response (Canning et al. 2004). This suggested that activation of $\mathrm{C}$-fibres does not incite cough per se. In several studies, the systemic administration of capsaicin actually inhibited cough following mechanical stimulation of the upper airways in anaesthetized animals (Tatar et al. 1988, 1994). In contrast to these findings, the subthreshold stimulation of C-fibres by capsaicin 
or bradykinin administered topically to the lung increased cough sensitivity to mechanical irritation of the upper airways (Mazzone et al. 2005) and could therefore help to explain why direct stimulation of these nerves is not necessary to induce cough per se, but is likely to 'sensitize' the cough reflex.

\subsection{Slowly Adapting Stretch Receptors}

The role of SARs in cough has received very little attention, although they are not believed to be directly involved, as their activity is not altered by stimuli evoking cough. However, experimental evidence in cats and rabbits suggested that SARs may facilitate the cough reflex, via interneurones called 'pump cells', by mechanisms that remain to be established, which either permit or augment the cough reflex due to RAR activity (Shannon et al. 2000).

\section{Antitussive Drugs}

Most cough treatments are designed to target the underlying disease which can cause cough as a symptom. However, there are a range of drugs available which directly target neuronal pathways (Fig. 1).

\subsection{Sodium Channel Blockers}

At least nine subtypes of sodium channels have been characterized (Alexander et al. 2007) and of particular interest are the tetrodotoxin-insensitive sodium channels ( $\mathrm{Na}_{V} 1.8, \mathrm{Na}_{V}$ 1.9) expressed on pulmonary C-fibres (Kwong and Lee 2005).

Local anaesthetics such as lidocaine, benzonatate and mexiletine are the most consistently effective peripherally acting antitussive drugs used to treat cough that is resistant to other treatments; however, their effects are transient and their repeated use is associated with tachyphylaxis, making high doses necessary, which can lead to unwanted side effects (Yukioka et al. 1985). Their mechanism of action is believed to be through use-dependent inhibition of voltage-gated sodium channels, thereby reducing action potential generation and transmission in afferent nerves. However, whilst topical administration of lidocaine to the airways has been reported to inhibit cough induced by capsaicin in healthy subjects (Choudry et al. 1990), the orally acting local anaesthetic mexiletine only attenuated cough induced by tartaric acid and not by capsaicin (Fujimura et al. 2000). The explanation for these observations might be explained by pharmacodynamic differences due to the routes of drug administration, although this remains to be determined.

RSD 931 is a quaternary ammonium compound (carcainium chloride) and a structural analogue of lidocaine, that exhibits antitussive activity in both guinea 


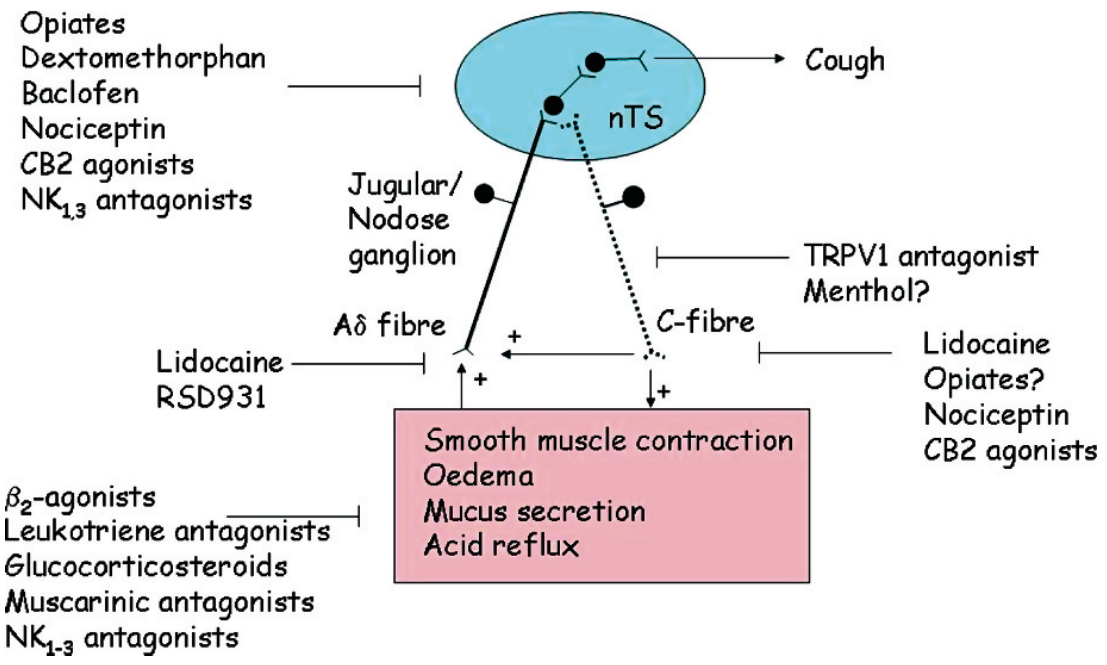

Fig. 1 The cough reflex and sites of action of some antitussive agents. Airway sensory nerves activated in response to a protussive stimulus travel though the vagus nerve to the medulla, where they terminate in the nucleus tractus solitarius (nTS). Second-order neurons relay the message to the respiratory pattern generator, which modifies the activity of the inspiratory and expiratory motor neurons and leads to cough. Antitussives can act peripherally at the level of the airway receptors or on nerve conduction. They can also act centrally, both presynaptically and postsynaptically. $\mathrm{C}$-fibres are depicted as playing a role in facilitating nTS activity. The activation of their terminal processes by inflammatory mediators such as 15-hydroperoxyeicosatetraenoic acid, bradykinin, $N$ arachidonoyl dopamine or low $\mathrm{pH}$ stimulates $\mathrm{C}$-fibre input into the $\mathrm{nTS}$, thereby facilitating central processing of afferent information received from $A \delta$-fibres innervating the proximal airways. Also note that the $\mathrm{A} \delta$-fibres shown consist of nociceptive $\mathrm{A} \delta$-fibres, 'cough' receptor and rapidly adapting receptors. It is the lattermost subset which can be activated by sensory neuropeptides either directly or indirectly via bronchoconstriction, oedema and mucus secretion

pigs and rabbits (Adcock et al. 2003). Whilst RSD 931 is a weak local anaesthetic, in the rabbit it only inhibited spontaneous and histamine-evoked discharges from A $\delta$-fibres, whilst modestly activating pulmonary C-fibres, which is distinctive from the effect of lidocaine, which suppressed all nerve fibres in the airway (Adcock et al. 2003). Such results suggest that RSD931 is antitussive via a selective effect on $\mathrm{A} \delta$-fibres independent of local anaesthetic effects. Another structurally related analogue of lidocaine, JMF2-1, has also been described to have anti-inflammatory activity and to be able to inhibit bronchospasm, whilst being 2 orders of magnitude weaker than lidocaine as a $\mathrm{Na}^{+}$channel blocker (da Costa et al. 2007), although it is unclear whether this agent has antitussive activity.

Citric acid is a tussive stimulus that is thought to cause cough by direct activation of a recently described subset of A $\delta$ fibres referred to as 'cough' receptors (Canning et al. 2004). The precise molecular target for citric acid on these nerves has not been identified, but pharmacological studies suggested the potential involvement of acid-sensing ion channels (ASICs) (Canning et al. 2006). ASICs are members of the $\mathrm{Na}^{+}$channel superfamily that includes the epithelium $\mathrm{Na}^{+}$channel $(\mathrm{ENaC})$ 
and the degenerins (DEG) that support $\mathrm{Na}^{+}$conductance in response to lowering of extracellular $\mathrm{pH}$. The activation of these ion channels on afferent nerves either in the oesophagus or following microaspiration of acid into the respiratory tract has been implicated in the cough resulting from gastro-oesophageal reflux (Kollarik et al. 2007). Amiloride is a non-selective inhibitor of ASICs and partially inhibited cough induced by citric acid in an anaesthetized-guinea-pig model (Canning et al. 2006), although an effect on other $\mathrm{Na}^{+}$channels in this response cannot be ruled out. These experimental data are also consistent with a report showing the ability of amiloride to suppress cough induced by acetic acid in asthmatic children (Mochizuki et al. 1995), although whether inhibition of ASICs on epithelial cells resulting in changes in local concentration of ions (e.g. chloride) was responsible for this antitussive action remains to be established. The development of subtypeselective ASIC channel blockers will be useful for further investigation of the role of these ion channels in the cough response, and to ascertain their utility as antitussive drugs.

\subsection{Tachykinin Receptor Antagonists}

Tachykinins are a group of peptides, including substance $\mathrm{P}$, neurokinin A and neurokinin $\mathrm{B}$, which are located in the peripheral endings of capsaicin-sensitive primary afferent neurones (C-fibres). Neuropeptides have been implicated in cough as their release from C-fibres may stimulate RARs either directly, or indirectly as a consequence of airway smooth-muscle contraction and increased vascular permeability leading to mucosal oedema and/or mucus secretion (Widdicombe 1995). Hence, tachykinin antagonists are most likely to act in the peripheral lung to inhibit the actions of endogenously released neuropeptides and thereby ameliorate cough to tussive agents which also stimulate the activation and release of sensory neuropeptides from sensory C-fibres (e.g. citric acid).

However, direct stimulation of the 'cough receptor' in anaesthetized guinea pigs by citric acid was unaffected by systemic or topical application of neurokinin antagonists, thereby ruling out a role for the release of sensory neuropeptides into the airways and subsequent modulation of the activity of these A $\delta$-fibres (Canning et al. 2006; Mazzone et al. 2005). In contrast, administration of neurokinin antagonists directly into the nTS, whilst not preventing cough per se, did attenuate the sensitization of the cough reflex following local application of capsaicin to the airways (Mazzone et al. 2005). Therefore, a central site of action cannot be entirely ruled out in view of the purported role of brainstem neuropeptides in central sensitization (Mazzone et al. 2005).

A number of potent tachykinin antagonists have been developed as antitussive drugs. The $\mathrm{NK}_{1}$ antagonists FK 888, CP-99,994 and NKP608 inhibited cough induced by tobacco smoke and citric acid in guinea pigs, and mechanical stimulation of the trachea in anesthetized cats (Bolser et al. 1997; Chapman et al. 2004; ElHashim et al. 2004; Yasumitsu et al. 1996). CP-99,994 can cross the blood-brain 
barrier and interference with neuropeptide transmission within the nTS and/or other regions of the CNS involved in cough may have accounted for the antitussive activity of this drug (Bolser et al. 1997). However, in healthy human subjects CP-99,994 did not inhibit bronchoconstriction or cough induced by hypertonic saline (Fahy et al. 1995), which is consistent with the view that the cough receptor is distinct from nociceptors.

The neurokinin $2\left(\mathrm{NK}_{2}\right)$ receptor antagonist (SR 48968) suppressed the cough reflex and was more potent than codeine in the guinea pig (Girard et al. 1995). Interestingly both SR48968 and codeine only partially inhibited the cough reflex when administered by the inhaled route (Advenier and EmondsAlt 1996; Yasumitsu et al. 1996), possibly reflecting differences in the concentration of these antagonists at receptor sites following the different routes of administration.

Neurokinin $3\left(\mathrm{NK}_{3}\right)$ receptors have received very little attention in relation to the cough reflex. Nevertheless the $\mathrm{NK}_{3}$ receptor antagonist SR142,801 inhibited cough induced by citric acid in guinea pigs and in pigs (Daoui et al. 1998; Moreaux et al. 2000). Another high-binding-affinity, non-peptide $\mathrm{NK}_{3}$ receptor antagonist, SB 235375 (Giardina et al. 1996), having low CNS penetration, was also effective against cough in the guinea pig (Hay et al. 2002) and could be a useful compound as a novel peripherally acting antitussive drug.

\subsection{NOP Receptor Agonists}

Nociceptin/orphanin FQ (NOP) is an opioid-like peptide and is the endogenous ligand for the NOP1 receptor (Meunier et al. 1995). NOP1 receptors are $\mathrm{G}_{\mathrm{i} / \mathrm{o}}$-coupled receptors that mediate presynpatic inhibition of neurotransmitter release (Meis and Pape 2001) and are widely distributed in the CNS and on peripheral airway nerves (Fischer et al. 1998). Nociceptin has been found to inhibit the release of sensory neuropeptides following depolarization of C-fibres (Shah et al. 1998), but interestingly did not prevent neuropeptide release from C-fibre terminal endings following direct activation of TRPV1 (Fischer et al. 1998; Shah et al. 1998). However, the antidromic stimulation of C-fibres by capsaicin is sensitive to nociceptin (Corboz et al. 2000), presumably reflecting a preferential inhibition of the opening of N-type calcium channels induced by this stimulus (Buchan and Adcock 1992).

Nociceptin inhibited cough induced by mechanical stimuli and capsaicin in guinea pigs and cats (McLeod et al. 2002) and induced by citric acid in guinea-pigs (Lee et al. 2006), and the antitussive action of the non-peptide NOP agonist Ro-646198 demonstrates the possibility of developing novel drugs free from side effects normally associated with opioid treatment (McLeod et al. 2004). Hence, NOP1 receptors are involved in the modulation of the cough reflex and selective NOP1 agonists may have potential as novel peripherally acting antitussives, although to date there have been no studies with such drugs in humans. 


\subsection{Cannabinoids}

The psychotropic effects of smoking cannabis are due to the pharmacological action of the active constituent (-)- $\Delta^{9}$-tetrahydrocannabinol (THC) within the CNS. In the airways, THC has been shown to cause both bronchodilation and bronchoconstriction in non-diseased subjects and asthmatic patients (Tashkin et al. 1977). However, an early report suggested that THC may have antitussive properties in an experimental model of cough induced by mechanical irritation of the tracheal mucosal surface in cats (Gordon et al. 1976). The discovery of cannabinoid (CB) receptors has renewed interest in the possible antitussive efficacy of CBs.

$\mathrm{CB}$ receptors are $\mathrm{G}_{\mathrm{i} / \mathrm{o}}$-coupled receptors that mediate presynpatic inhibition of neurotransmitter release (Freiman and Szabo 2005; Melis et al. 2004; Soya et al. 2005). $\mathrm{CB}_{1}$ receptors are predominantly located within the CNS but are also expressed by non-neuronal cells (e.g. lymphocytes), whilst $\mathrm{CB}_{2}$ receptors are primarily found on immune cells (Pacher et al. 2006). It was reported that within the airways, $\mathrm{CB}_{1}$ receptors were found on sensory nerves and cough induced by capsaicin was augmented by the $\mathrm{CB}_{1}$ receptor antagonist SR14167A, but not by the $\mathrm{CB}_{2}$ selective antagonist SR144528 (Calignano et al. 2000). These findings could be explained by the well-known inverse agonist activity of SR14167A, although this agent did not cause cough per se when administered alone. It was concluded that the increased cough response following administration of SR14167A was most likely a consequence of the antagonism of the antitussive action of endogenously released endocannabinoids in the airways (Calignano et al. 2000). However, this conclusion is complicated by the fact that cough was elicited in guinea pigs following aerosol exposure to the endogenous endocannabinoid anandamide (Jia et al. 2002). Anandamide was initially described as an endogenous activator of CB receptors, but it can also activate TRPV1 receptors (Smart et al. 2000; Zygmunt et al. 1999). As a consequence, its effect on cough is variable and may be dependent on the balance between CB and TRPV1 activity (Calignano et al. 2000; Jia et al. 2002).

In stark contrast to these findings, an agonist selective for the $\mathrm{CB}_{2}$ receptors was reported to suppress cough induced by citric acid in guinea pigs (Patel et al. 2003). A peripheral mechanism of action was implied since the $\mathrm{CB}_{2}$ selective agonist JWH 133 inhibited the depolarization of isolated vagus nerve from both guinea pigs and humans, in response to capsaicin in vitro (Patel et al. 2003). Moreover, the antitussive action of CBs is not likely to be mediated by suppression of neuropeptide release from the peripheral terminals of $\mathrm{C}$-fibres in the airways, since the non-selective CB agonist CP 55940 was without significant effect on the contraction of airway smooth muscle, owing to the release of sensory neuropeptides, following electrical stimulation of C-fibres (Tucker et al. 2001). However, it is not known whether the antitussive action of JWH-133 also occurred within the cough circuitry of the nTS as the nucleus is rich in CB receptors (Mailleux and Vanderhaeghen 1992). 


\subsection{Drugs Targeting Transient Receptor Potential Channels}

Transient receptor potential (TRP) channels play an important role in a diversity of sensory function, including taste, smell, hearing and perception of pain. This family comprises proteins with six transmembrane-spanning domains that are assembled either as homotetramers or heterotetramers to form non-selective cation channels permeable to calcium and sodium ions. There are at least six subfamilies, including TRPC (canonical), TRPM (melastatin), TRPV (vanilloid), TRPA (ankyrin), TRPML (mucolipin) and TRPP (polycystin) (Nilius et al. 2007).

One particular member of this superfamily (TRPV1) is predominantly localized to small-diameter peptidergic and nonpeptidergic neurones in dorsal and vagal sensory ganglia (Szallasi and Blumberg 1999) and activation of this channel by capsaicin gives rise to feelings of warmth and pain. The cloning and expression of TRPV1 has led to a greater appreciation of the role this channel plays in various pathophysiological pain states (Caterina et al. 1997). TRPV1 receptors are polymodal, activated by protons, heat (Caterina et al. 1997) and a range of lipid mediators such as 15-hydroperoxyeicosatetraenoic acid (15-HPETE) (Hwang et al. 2000), $N$-arachidonoyl dopamine (NADA) (Huang et al. 2002) and anandamide (Smart et al. 2000; Zygmunt et al. 1999) and indirectly by bradykinin (Chuang et al. 2001; Shin et al. 2002) and nerve growth factor (NGF) (Chuang et al. 2001). The release of these mediators during an inflammatory insult can result in the activation of TRPV1, thereby potentially leading to the cascade of events culminating in the sensitization of the cough reflex (Fig. 1).

An upper respiratory tract infection can increase cough sensitivity to citric acid in humans (Empey et al. 1976). Similarly, cough induced by capsaicin is increased in subjects with respiratory inflammatory diseases such as asthma, COPD and idiopathic cough (Doherty et al. 2000; Hathaway et al. 1993; Hope-Gill et al. 2003; O'Connell et al. 1996), indicating that mediators released during an inflammatory response within the respiratory tract increase cough sensitivity. It is speculated that in chronic diseases this process may result in plasticity changes in sensory function and pattern of innervation within the respiratory tract. The density of TRPV1-immunoreactive nerves in the airways is elevated in bronchial biopsies from individuals with chronic cough (Groneberg et al. 2004) and it has been reported that the density of substance P (Lee et al. 2003) and CGRP (O'Connell et al. 1995) immunoreactive nerves is increased in cough-variant asthma and chronic cough of unknown cause, respectively.

These clinical observations suggest that neuronal innervation patterns and perhaps function might underlie the physiological manifestation of hypertussive cough responses in these pathological conditions. Interference with the function of these afferent nerves might offer a selective and novel therapeutic approach to the treatment of cough. A number of studies have shown that TRPV1 antagonists, including ruthenium red (Bolser 1991), capsazepine (Lalloo et al. 1995), 5'-iodoresiniferatoxin (Trevisani et al. 2004) and $N$-(4-tertiary-butylphenyl)-4-(3-cholrophyridin-2-yl)tetrahydropyrazine-1 $2 \mathrm{H}$ )-carboxamide (McLeod et al. 2006) reduced cough in response to a variety of tussive stimuli (e.g. capsaicin, citric acid and allergen). 
Similarly, the chemical inactivation of sensory C-fibres suppressed the ability of guinea pigs to cough in response to capsaicin and citric acid (Forsberg et al. 1988), confirming the importance of $\mathrm{C}$-fibres in this response. However, the role of C-fibres in causing cough per se has been questioned (see above) and in some experimental models stimulation of C-fibres does not evoke cough (Canning et al. 2004), and may even inhibit cough (Tatar et al. 1988, 1994), whilst subacute stimulation of C-fibres can lead to an increase in the cough response to tussive stimuli such as citric acid. This has led to the proposal that activation of C-fibres can alter the threshold for cough, an interaction that is likely to be modulated at the level of the nTS (Mazzone et al. 2005). Hence, drugs targeting TRPV1 may be of considerable utility as they might not inhibit defensive cough, but might serve to normalize the sensitized cough response.

Targeting the TRPV1 receptor may offer a new approach to the treatment of cough, since defensive cough might be unaffected. For example, chemical ablation of sensory C-fibres did not result in a loss of the tussive response following mechanical irritation of the airways (Forsberg et al. 1988), nor did capsazepine affect cough induced by hypertonic saline (Lalloo et al. 1995). This would imply that TRPV1 antagonists would not affect the 'hard-wiring' pathways mediating defensive cough, but may be of potential use under conditions where there is sensitization of the cough reflex via activation of TRPV1-sensitive afferents. In contrast to these observations, one study has shown that whilst capsazepine did not inhibit cough in response to citric acid per se (Canning et al. 2006), it did inhibit the TRPV1-dependent sensitization of the cough reflex (Mazzone et al. 2005). Therefore, TRPV1 antagonists may actually reduce the sensitization of the cough reflex that occurs as a consequence of the activation of these receptors on afferent nerve terminals following release of endogenous activators (e.g. 15-HPETE, bradykinin, NADA, NGF, pH).

One study has suggested that TRPV1 antagonism may not be a useful approach in suppressing all forms of hypertussive cough. In a model of hypertussive cough following cigarette exposure, neither capsazepine nor $5^{\prime}$-iodoresiniferatoxin inhibited cough in response to citric acid or capsaicin, despite the fact that a dual $\mathrm{NK}_{1,2}$ receptor antagonist was effective in this model (Lewis et al. 2007). It was unclear from this study whether the two TRPV1 antagonists inhibited cough to these tussive stimuli in air-exposed animals, but if this is the case, then sensory activation occurred independently of TRPV1 during smoke exposure. The implication of these studies is that other ion channels (e.g. ASICs) play a complementary role in modulating cough under certain pathological conditions and, therefore, development of TRPV1 antagonists may not be applicable to all forms of hypertussive cough; and desensitization of sensory C-fibres with partial TRPV1 agonists may offer a better approach to suppress sensory input into the nTS than TRPV1 antagonists.

The role of other TRP channels in regulating sensory nerve function has been investigated, although to what extent these channels contribute towards cough remains to be established. Of particular interest is the recognition that menthol, an ingredient of many over-the-counter cough remedies, is antitussive in humans (Morice et al. 1994) and guinea pigs (Laude et al. 1994), and, furthermore, is now appreciated to be an activator of TRPM8 (McKemy et al. 2002), a channel that plays a major 
role in cold thermosensation (Bautista et al. 2007). Interestingly, menthol is also an antagonist of TRPA1 channels, which are activated by mustard oil and a range of lipid mediators derived from oxidative stress (Macpherson et al. 2007). Whether targeting these channels on sensory nerves will yield novel drugs with antitussive activity remains to be established.

\subsection{Ion Channel Modulators}

NS1619 is a selective opener of calcium-activated potassium channels resulting in hyperpolarization and reduced cell excitability. In the airways, topical application of NS1619 inhibited cough induced by citric acid and bradykinin, the mechanism of action of which has been suggested to be via the suppression of impulses in guinea pig tracheal A $\delta$ - and C-fibres (Fox et al. 1997); however, clinical studies have not yet been reported with such drugs.

Moguisteine is a peripherally acting antitussive that may act as an ATP-sensitive $\mathrm{K}^{+}$channel opener and in clinical trials was shown to reduce the frequency of cough in patients with lung cancer to a level comparable to that resulting from administration of codeine (Barnabe et al. 1995).

Furosemide is a loop diuretic, and suppressed cough induced by low-chloride solutions but not by capsaicin (Foresi et al. 1996; Karlsson et al. 1992; Mochizuki et al. 1995; Stone et al. 1993a; Ventresca et al. 1990). This drug blocks the $\mathrm{Na}^{+} / \mathrm{K}^{+} / 2 \mathrm{Cl}^{-}$cotransporter expressed in the peripheral terminals of the 'cough' receptor in guinea pigs (Mazzone and McGovern 2006) and laryngeal RARs in the dog (Sant'Ambrogio et al. 1993). The cotransporter facilitates the accumulation of chloride ions into the peripheral terminations of the cough receptor. It has been proposed that furosemide inhibits the effective accumulation of chloride ions into these terminations, thereby preventing nerve depolarization in response to opening of chloride ion channels in the membrane. Inhibitors of chloride channels, including $4,4^{\prime}$-diisothiocyanatostilbene-2,2' -disulfonic acid (a non-selective anion-channel inhibitor) and niflumic acid (a selective inhibitor of calcium activated chloride channels), also inhibited cough in response to citric acid (Mazzone and McGovern 2006). These channels offer attractive targets for the development of novel antitussive agents, although to target receptors and ion channels present on the 'cough' receptor which triggers an essential part of the 'hard-wired' cough reflex would probably be unwise.

\subsection{Leukotriene Receptor Antagonists}

Zafirlukast, a cysteinyl leukotriene antagonist, has shown therapeutic efficacy in cough-variant asthma, even in patients unresponsive to inhaled bronchodilators and corticosteroids (Dicpinigaitis et al. 2002), whist a similar drug, montelukast has also 
been demonstrated to be of utility in various cough syndromes (Bisgaard 2003; Kopriva et al. 2004), although there are too few clinical trials to determine whether this drug should be routinely used in patients with cough (Chang et al. 2006). The mechanism of action of these drugs as antitussives could stem from their ability to reduce mucus secretion, oedema and bronchoconstriction, which are all stimulated by leukotrienes and thereby indirectly facilitate action potential generation in sensitized afferent nerves. Alternatively, there is evidence supporting the view that leukotrienes may directly increase the excitability of afferent nerves (McAlexander et al. 1998; Undem and Weinreich 1993).

\subsection{Bradykinin Antagonists}

Captopril and enalapril are angiotensin converting enzyme (ACE) inhibitors and are often used in the treatment of hypertension. Cough is a side effect of these drugs in patients with irritable airways and is a result of inhibition of ACE, leading to a decreased metabolism and subsequent accumulation of bradykinin in the airways (Dicpinigaitis 2006a). Bradykinin caused cough when administered topically to the airways of healthy subjects (Choudry et al. 1989). Similarly, cough sensitivity to capsaicin, but not other tussive agents such as citric acid or distilled water, was increased if endogenous levels of bradykinin were elevated following treatment with an ACE inhibitor (Morice et al. 1987). Furthermore, experimental models have also demonstrated that bradykinin increased cough sensitivity to tussive stimuli (Mazzone et al. 2005) and pharmacological treatment with HOE-140, a $\mathrm{B}_{2}$ receptor antagonist, inhibited citric acid induced cough in the guinea pig (Featherstone et al. 1996). However, it remains to be seen whether $B_{2}$ receptor antagonists are antitussive in humans.

\subsection{Opioids}

Currently there are few effective cough suppressants and it has been concluded that patients requiring symptomatic relief in chronic cough derive a very low level of benefit from available drugs (Bolser 2006). Most effective are opioids such as codeine which produce a reduction in the frequency of cough of $19-60 \%$ (Bolser 2006; Morice et al. 2007). However, the usefulness of opioids is limited by their sedative properties and dependence liability (Bolser 2006).

Opioids such as codeine, morphine and dihydrocodone are all good antitussives primarily via their action at central $\mu$-opioid-receptors (Kamei 1996). It is not known, however, whether this occurs within the cough circuitry of the nTS, even though it is recognized that this location is rich in this receptor (MonteilletAgius et al. 1998). These receptors are $\mathrm{G}_{\mathrm{i} / \mathrm{o}}$-coupled and mediate presynaptic inhibition of neurotransmitter release (Emmerson and Miller 1999). Recently, both 
selective $\delta$-opioid receptor antagonists (TRK-851) and agonists (SB-227122) have been found to be antitussive in animal models (Chung 2003). Additionally, K-opioid receptor agonists have been reported to be anti-tussive (Kamei 1996). Therefore, modulation of previously untargeted central opioid receptors appears a promising avenue for the development of novel antitussive drugs.

Opioid receptors have also been located in the periphery, but their ability to exert considerable antitussive action at this level is debatable. Aerosol administration of codeine is not antitussive in humans challenged with capsaicin (Kamei 2002), and although the peripherally acting peptide BW443C is antitussive in animal studies (Adcock et al. 1988), there is only limited clinical evidence to support this antitussive effect in humans (Pavord et al. 1994).

\subsection{Sigma Receptor Ligands}

Dextromethorphan, the dextrorotatory optical isomer of the opioid levomethorphan, retains its antitussive action despite being inactive at opioid receptors. It has been reported that this drug is an agonist at the 'sigma-1' receptor (Guitart et al. 2004; Monnet 2005) and a non-competitive antagonist (channel blocker) of NMDA receptors (Franklin and Murray 1992; Netzer et al. 1993), actions that could have consequences for excitatory glutamatergic neurotransmission in the nTS.

It is thought that dextromethorphan and noscapine act on sigma receptors (centrally and peripherally) rather than at classic opioid receptors (Brown et al. 2004). However, the inhibitory effect of noscapine on the bradykinin $\mathrm{B}_{2}$ receptor (Ebrahimi et al. 2003) and dextromethorphan's activity at NMDA receptors (Brown et al. 2004) may also contribute to the antitussive activity of these drugs. Some research has been undertaken with newer, more efficacious sigma agonists such as SKF-10,047 (Brown et al. 2004), although plenty of opportunities remain for further investigation in this area.

\subsection{GABA Receptor Ligands}

GABA is an inhibitory neurotransmitter present centrally and in the peripheral nervous system. The $\mathrm{GABA}_{\mathrm{B}}$ receptor agonist baclofen has been shown to be antitussive centrally in animal studies and several clinical trials have proven its efficacy as an antitussive drug in humans (Dicpinigaitis and Gayle 2003a). An analogue of baclofen that does not cross the blood-brain barrier has also been shown experimentally to be antitussive (Bolser et al. 1994), suggesting that peripherally acting $\mathrm{GABA}_{\mathrm{B}}$ agonists may also be useful in the treatment of cough, particularly since the $\mathrm{GABA}_{\mathrm{A}}$ agonist muscimol administered locally to the mucosal surface augmented cough induced by citric acid in guinea pigs (Mazzone and McGovern 2006). 


\section{Challenges to the Development of Novel Antitussive Drugs}

The development of novel antitussives is a challenging area, not least because of the lack of good predictive models, both clinically and preclinically. For instance, it is highly debatable whether capsaicin challenge in healthy volunteers is a good cough model when many drugs which improve pathological cough fail to inhibit capsaicin-induced cough (Table 1). Similarly, the demonstration of antitussive activity of novel substances against stimuli used to induce tussive responses in humans rather than determining their effect on the natural history of cough is likely to lead to false-negatives. For example, opioids have been shown to reduce the frequency of cough in subjects with chronic cough, without altering cough sensitivity to citric acid (Morice et al. 2007). Therefore, non-invasive ambulatory monitoring of cough should be urgently validated as a method to assess the efficacy of novel antitussive agents.

Much of the preclinical work has also relied on using capsaicin-induced or citric acid induced cough in healthy guinea pigs and there are many examples of drugs that are antitussive in these preclinical models that do not show antitussive effects in humans. For example, $\mathrm{NK}_{1}$ antagonists had promising preclinical antitussive data experimentally that were not confirmed in clinical studies in humans (Joos et al. 2003). Following a similar pattern, $\mathrm{NK}_{1}$ antagonists attenuated nociceptive responses in animals but failed as analgesics in humans (Hill 2000). Furthermore, a dual dopamine D2 and $\beta_{2}$-adrenoceptor agonist was recently found not to improve the symptom of cough in a large clinical trial of patients with COPD despite exhibiting antitussive activity in animals (Laursen et al. 2003). The value and limitations of animal models of cough has been discussed elsewhere (Karlsson and Fuller 1999) and it would seem sensible to ensure that novel drugs exhibit antitussive activity in at least two species before being tried in humans and perhaps more importantly should exhibit antitussive activity in hypertussive models since the ultimate aim of antitussive therapy in the clinic is to reduce excess cough (sensitization of cough reflexes), rather than inhibiting cough altogether (i.e. the 'hard-wiring' cough reflex). Clearly there is an urgent need to develop more realistic models of cough preclinically and as importantly to consider the best way of evaluating novel antitussives in early clinical development for proof of concept before entering into larger clinical studies.

Furthermore, given the place of the nTS in the afferent arm of the cough reflex, we hypothesize that drugs that inhibit excitatory synaptic transmission in this nucleus will possess antitussive activity. Additionally this region of the brain lacks a complete blood-brain barrier and is therefore accessible to blood-borne drugs (Gross et al. 1990). Agonists acting at a range of receptors have been shown to act presynaptically to inhibit excitatory neurotransmission in the nTS (Brooks et al. 1992; Chen et al. 2002; Glatzer and Smith 2005; Kato and Shigetomi 2001; Sekizawa et al. 2003), though not in the context of the cough response. 


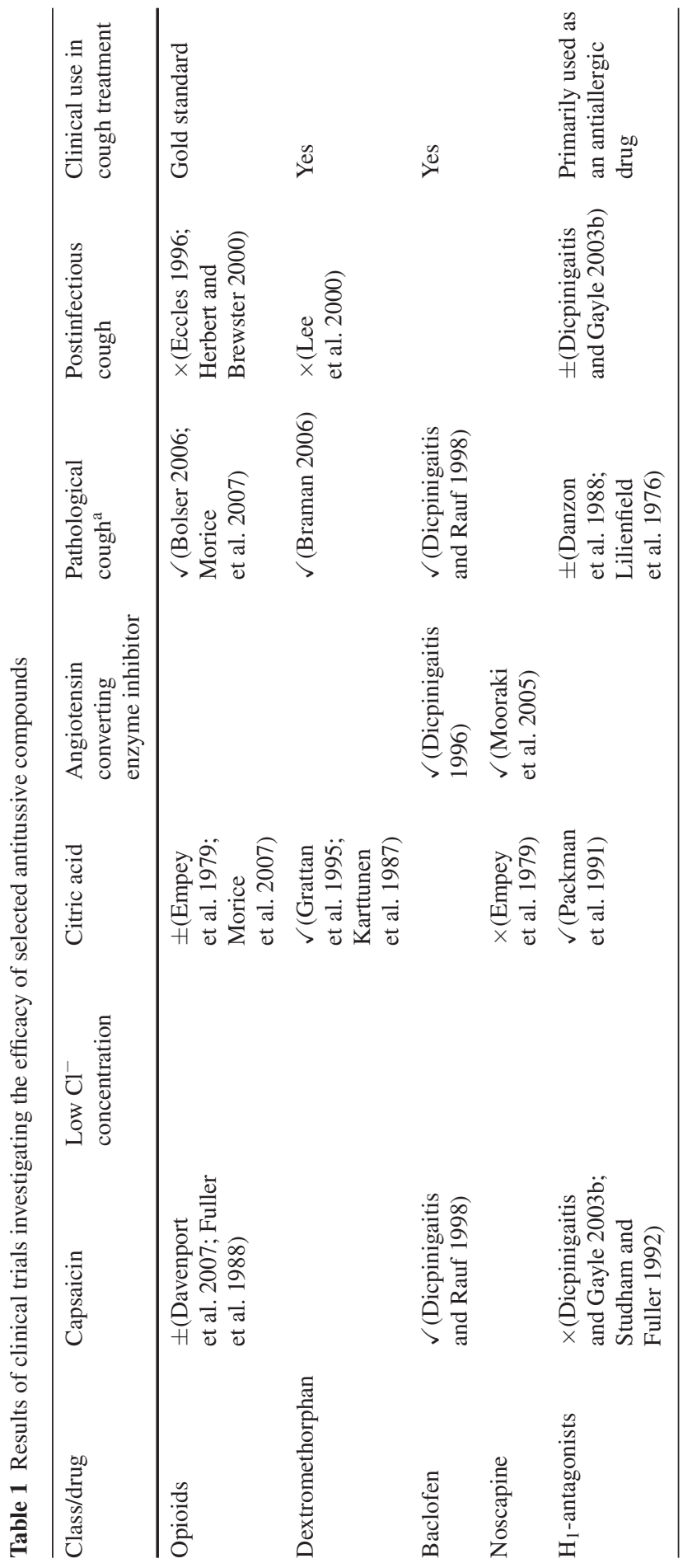




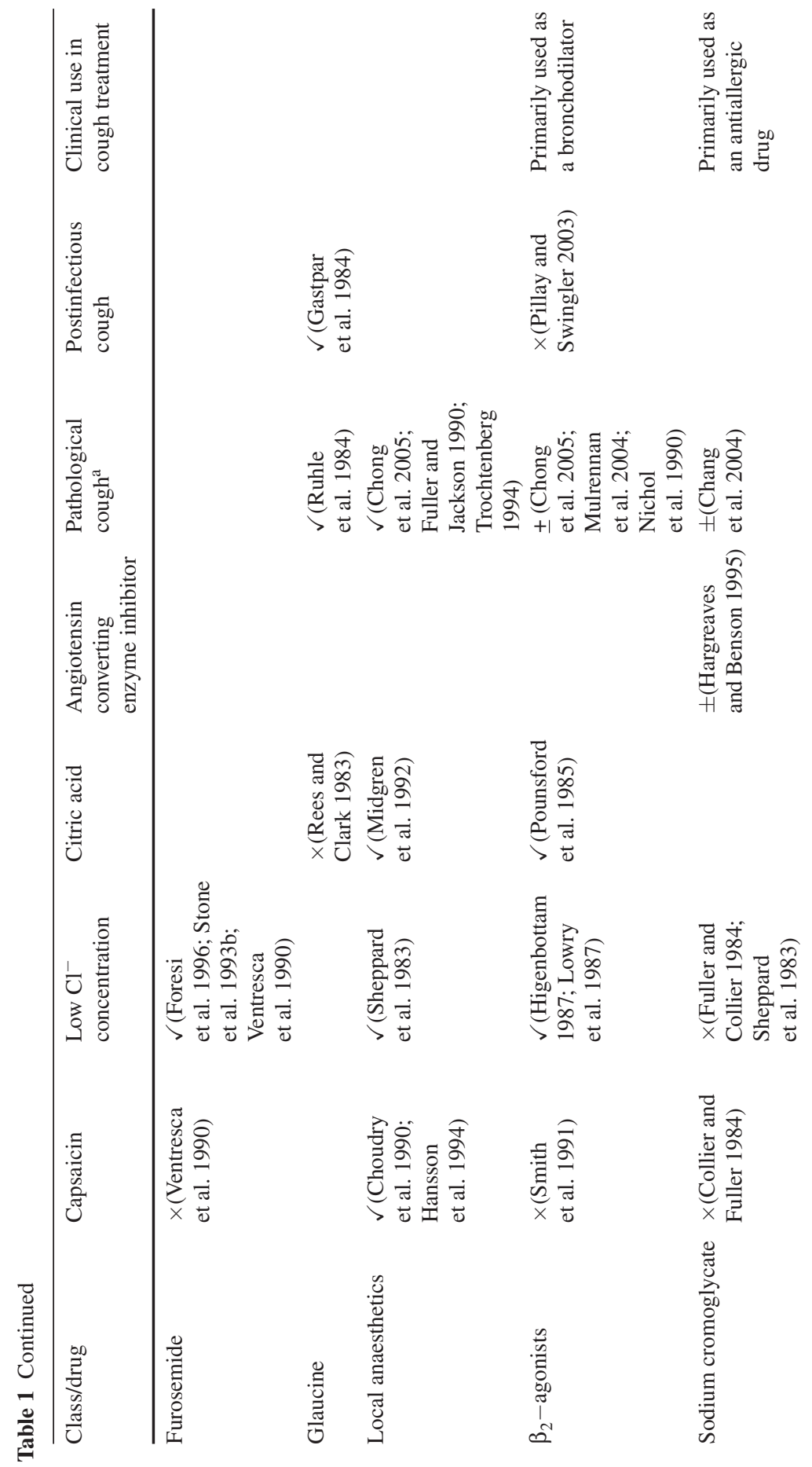




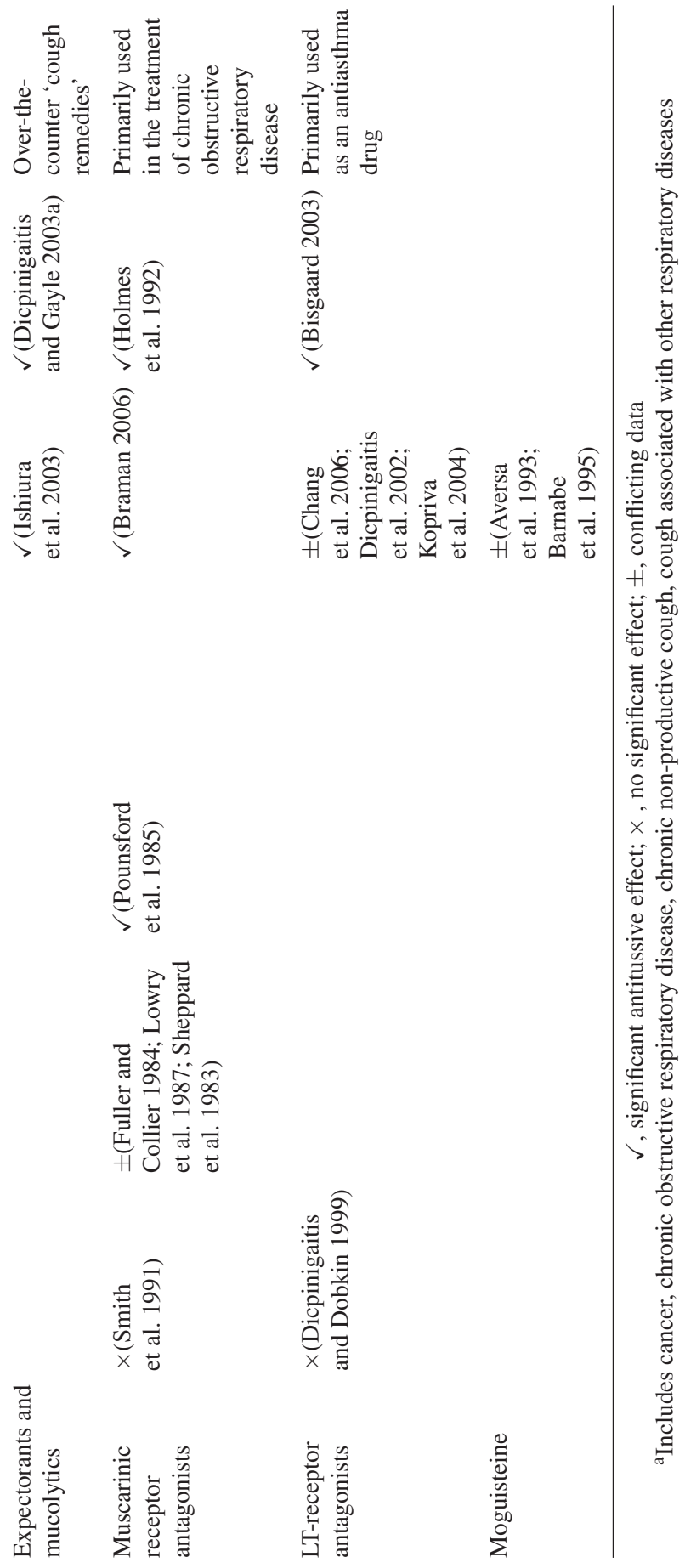




\section{Conclusion}

Our understanding of the reflexes involved in modulating cough and hypertussive responses is increasing, but there is still much to learn. Cough remains a relatively poorly studied area of pulmonary research when compared with bronchospasm and airway inflammation. However, there remains a clear need to develop a non-opioid antitussive drug that ideally modulates abnormal heightened cough reflexes, whilst leaving the normal cough reflex unaltered (Table 1, Fig. 1). Nonetheless, significant progress is being made to develop novel antitussive drugs and the growing recognition of cough as an unmet medical need will hopefully ensure there is more research into this important clinical problem.

\section{References}

Adcock JJ, Schneider C, Smith TW (1988) Effects of codeine, morphine and a novel opioid pentapeptide BW443C, on cough, nociception and ventilation in the unanaesthetized guinea-pig. Br J Pharmacol 93:93-100

Adcock JJ, Douglas GJ, Garabette M, Gascoigne M, Beatch G, Walker M, Page CP (2003) RSD931, a novel anti-tussive agent acting on airway sensory nerves. Br J Pharmacol 138: 407-416

Advenier C, EmondsAlt X (1996) Tachykinin receptor antagonists and cough. Pulm Pharmacol 9:329-333

Alexander SP, Mathie A, Peters JA (2007) Ion channels. Br J Pharmacol 150(Suppl 1):S96-S121

Andresen MC, Yang M (1995) Dynamics of sensory afferent synaptic transmission in aortic baroreceptor regions on nucleus tractus solitarius. J Neurophysiol 74:1518-1528

Aversa C, Cazzola M, Clini V, Dal NR, Maiorano V, Tana F, Allegra L (1993) Clinical trial of the efficacy and safety of moguisteine in patients with cough associated with chronic respiratory diseases. Drugs Exp Clin Res 19:273-279

Bailey CP, Maubach KA, Jones RS (2004) Neurokinin-1 receptors in the rat nucleus tractus solitarius: Pre- and postsynaptic modulation of glutamate and GABA release. Neuroscience 127: 467-479

Barnabe R, Berni F, Clini V, Pirrelli M, Pisani CA, Robuschi M, Rossi M, Sestini P, Tana F, Vaghi A (1995) The efficacy and safety of moguisteine in comparison with codeine phosphate in patients with chronic cough. Monaldi Arch Chest Dis 50:93-97

Bautista DM, Siemens J, Glazer JM, Tsuruda PR, Basbaum AI, Stucky CL, Jordt SE, Julius D (2007) The menthol receptor TRPM8 is the principal detector of environmental cold. Nature 448:204-208

Bisgaard H (2003) A randomized trial of montelukast in respiratory syncytial virus postbronchiolitis. Am J Respir Crit Care Med 167:379-383

Bolser DC (1991) Fictive cough in the cat. J Appl Physiol 71:2325-2331

Bolser DC (2006) Cough suppressant and pharmacologic protussive therapy: ACCP evidencebased clinical practice guidelines. Chest 129:238S-249S

Bolser DC, DeGennaro FC, O'Reilly S, Chapman RW, Kreutner W, Egan RW, Hey JA (1994) Peripheral and central sites of action of GABA-B agonists to inhibit the cough reflex in the cat and guinea pig. Br J Pharmacol 113:1344-1348

Bolser DC, DeGennaro FC, O'Reilly S, McLeod RL, Hey JA (1997) Central antitussive activity of the NK1 and NK2 tachykinin receptor antagonists, CP-99,994 and SR 48968, in the guinea-pig and cat. Br J Pharmacol 121:165-170 
Bonham AC, Chen CY, Mutoh T, Joad JP (2001) Lung C-fiber CNS reflex: Role in the respiratory consequences of extended environmental tobacco smoke exposure in young guinea pigs. Environ Health Perspect 109(Suppl 4):573-578

Bonham AC, Sekizawa SI, Joad JP (2004) Plasticity of central mechanisms for cough. Pulm Pharmacol Ther 17:453-457

Bonham AC, Chen CY, Sekizawa S, Joad JP (2006a) Plasticity in the nucleus tractus solitarius and its influence on lung and airway reflexes. J Appl Physiol 101:322-327

Bonham AC, Sekizawa S, Chen CY, Joad JP (2006b) Plasticity of brainstem mechanisms of cough. Respir Physiol Neurobiol 152:312-319

Braman SS (2006) Chronic cough due to chronic bronchitis: ACCP evidence-based clinical practice guidelines. Chest 129:104S-115S

Brooks PA, Glaum SR, Miller RJ, Spyer KM (1992) The actions of baclofen on neurones and synaptic transmission in the nucleus tractus solitarii of the rat in vitro. J Physiol 457:115-129

Brown C, Fezoui M, Selig WM, Schwartz CE, Ellis JL (2004) Antitussive activity of sigma-1 receptor agonists in the guinea-pig. Br J Pharmacol 141:233-240

Buchan P, Adcock JJ (1992) Capsaicin-induced bronchoconstriction in the guinea-pig: Contribution of vagal cholinergic reflexes, local axon reflexes and their modulation by BW443C. Br J Pharmacol 105:448-452

Calignano A, Katona I, Desarnaud F, Giuffrida A, La RG, Mackie K, Freund TF, Piomelli D (2000) Bidirectional control of airway responsiveness by endogenous cannabinoids. Nature 408: 96-101

Canning BJ (2006) Anatomy and neurophysiology of the cough reflex: ACCP evidence-based clinical practice guidelines. Chest 129:33S-47S

Canning BJ, Mazzone SB, Meeker SN, Mori N, Reynolds SM, Undem BJ (2004) Identification of the tracheal and laryngeal afferent neurones mediating cough in anaesthetized guinea-pigs. $\mathrm{J}$ Physiol 557:543-558

Canning BJ, Farmer DG, Mori N (2006) Mechanistic studies of acid-evoked coughing in anesthetized guinea pigs. Am J Physiol Regul Integr Comp Physiol 291:R454-R463

Carr MJ, Hunter DD, Jacoby DB, Undem BJ (2002) Expression of tachykinins in nonnociceptive vagal afferent neurons during respiratory viral infection in guinea pigs. Am J Respir Crit Care Med 165:1071-1075

Caterina MJ, Schumacher MA, Tominaga M, Rosen TA, Levine JD, Julius D (1997) The capsaicin receptor: A heat-activated ion channel in the pain pathway. Nature 389:816-824

Caudle RM, Perez FM, Del Valle-Pinero AY, Iadarola MJ (2005) Spinal cord NR1 serine phosphorylation and NR2B subunit suppression following peripheral inflammation. Mol Pain 1:25

Chang A, Marchant JM, McKean M, Morris P (2004) Inhaled cromones for prolonged non-specific cough in children. Cochrane Database Syst Rev CD004436

Chang AB, Winter D, Acworth JP (2006) Leukotriene receptor antagonist for prolonged nonspecific cough in children. Cochrane Database Syst Rev CD005602

Chapman RW, House A, Liu F, Celly C, Mei H, Hey JA (2004) Antitussive activity of the tachykinin NK1 receptor antagonist, CP-99994, in dogs. Eur J Pharmacol 485:329-332

Chen CY, Horowitz JM, Bonham AC (1999) A presynaptic mechanism contributes to depression of autonomic signal transmission in NTS. Am J Physiol 277:H1350-H1360

Chen CY, Bonham AC, Schelegle ES, Gershwin LJ, Plopper CG, Joad JP (2001) Extended allergen exposure in asthmatic monkeys induces neuroplasticity in nucleus tractus solitarius. J Allergy Clin Immunol 108:557-562

Chen CY, Ling Eh EH, Horowitz JM, Bonham AC (2002) Synaptic transmission in nucleus tractus solitarius is depressed by group II and III but not group I presynaptic metabotropic glutamate receptors in rats. J Physiol 538:773-786

Chen CY, Bonham AC, Plopper CG, Joad JP (2003) Neuroplasticity in nucleus tractus solitarius neurons after episodic ozone exposure in infant primates. J Appl Physiol 94:819-827

Chong CF, Chen CC, Ma HP, Wu YC, Chen YC, Wang TL (2005) Comparison of lidocaine and bronchodilator inhalation treatments for cough suppression in patients with chronic obstructive pulmonary disease. Emerg Med J 22:429-432 
Choudry NB, Fuller RW, Pride NB (1989) Sensitivity of the human cough reflex: Effect of inflammatory mediators prostaglandin E2, bradykinin, and histamine. Am Rev Respir Dis 140: $137-141$

Choudry NB, Fuller RW, Anderson N, Karlsson JA (1990) Separation of cough and reflex bronchoconstriction by inhaled local anaesthetics. Eur Respir J 3:579-583

Chuang HH, Prescott ED, Kong H, Shields S, Jordt SE, Basbaum AI, Chao MV, Julius D (2001) Bradykinin and nerve growth factor release the capsaicin receptor from PtdIns $(4,5) \mathrm{P} 2$-mediated inhibition. Nature 411:957-962

Chung KF (2003) Current and future prospects for drugs to suppress cough. IDrugs 6:781-786

Colin I, Blondeau C, Baude A (2002) Neurokinin release in the rat nucleus of the solitary tract via NMDA and AMPA receptors. Neuroscience 115:1023-1033

Collier JG, Fuller RW (1984) Capsaicin inhalation in man and the effects of sodium cromoglycate. Br J Pharmacol 81:113-117

Cook AJ, Woolf CJ, Wall PD, McMahon SB (1987) Dynamic receptive field plasticity in rat spinal cord dorsal horn following C-primary afferent input. Nature 325:151-153

Corboz MR, Rivelli MA, Egan RW, Tulshian D, Matasi J, Fawzi AB, Benbow L, Smith-Torhan A, Zhang H, Hey JA (2000) Nociceptin inhibits capsaicin-induced bronchoconstriction in isolated guinea pig lung. Eur J Pharmacol 402:171-179

Cullinan P (1992) Persistent cough and sputum: Prevalence and clinical characteristics in south east England. Respir Med 86:143-149

da Costa JC, Olsen PC, de Azeredo SR, de FC, V, Serra MF, Alves LA, Faria RX, Xisto DG, Rocco PR, Cordeiro RS, Rodrigues E Silva PM, Martins MA (2007) JMF2-1, a lidocaine derivative acting on airways spasm and lung allergic inflammation in rats. J Allergy Clin Immunol 119:219-225

Danzon A, Lacroix J, Infante-Rivard C, Chicoine L (1988) A double-blind clinical trial on diphenhydramine in pertussis. Acta Paediatr Scand 77:614-615

Daoui S, Cognon C, Naline E, Emonds-Alt X, Advenier C (1998) Involvement of tachykinin NK3 receptors in citric acid-induced cough and bronchial responses in guinea pigs. Am J Respir Crit Care Med 158:42-48

Davenport PW, Bolser DC, Vickroy T, Berry RB, Martin AD, Hey JA, Danzig M (2007) The effect of codeine on the urge-to-cough response to inhaled capsaicin. Pulm Pharmacol Ther 20: 338-346

Dicpinigaitis PV (1996) Use of baclofen to suppress cough induced by angiotensin- converting enzyme inhibitors. Ann Pharmacother 30:1242-1245

Dicpinigaitis PV (2004) Potential new cough therapies. Pulm Pharmacol Ther 17:459-462

Dicpinigaitis PV (2006a) Angiotensin-converting enzyme inhibitor-induced cough: ACCP evidence-based clinical practice guidelines. Chest 129:169S-173S

Dicpinigaitis PV (2006b) Potential future therapies for the management of cough: ACCP evidencebased clinical practice guidelines. Chest 129:284S-286S

Dicpinigaitis PV, Dobkin JB (1999) Effect of zafirlukast on cough reflex sensitivity in asthmatics. J Asthma 36:265-270

Dicpinigaitis PV, Rauf K (1998) Treatment of chronic, refractory cough with baclofen. Respiration 65:86-88

Dicpinigaitis PV, Dobkin JB, Rauf K, Aldrich TK (1998) Inhibition of capsaicin-induced cough by the gamma-aminobutyric acid agonist baclofen. J Clin Pharmacol 38:364-367

Dicpinigaitis PV, Dobkin JB, Reichel J (2002) Antitussive effect of the leukotriene receptor antagonist zafirlukast in subjects with cough-variant asthma. J Asthma 39:291-297

Dicpinigaitis PV, Gayle YE (2003a) Effect of guaifenesin on cough reflex sensitivity. Chest 124:2178-2181

Dicpinigaitis PV, Gayle YE (2003b) Effect of the second-generation antihistamine, fexofenadine, on cough reflex sensitivity and pulmonary function. Br J Clin Pharmacol 56:501-504

Doherty MJ, Mister R, Pearson MG, Calverley PM (2000) Capsaicin responsiveness and cough in asthma and chronic obstructive pulmonary disease. Thorax 55:643-649 
Drewe JA, Miles R, Kunze DL (1990) Excitatory amino acid receptors of guinea pig medial nucleus tractus solitarius neurons. Am J Physiol 259:H1389-H1395

Duggan AW, Hope PJ, Jarrott B, Schaible HG, Fleetwood-Walker SM (1990) Release, spread and persistence of immunoreactive neurokinin A in the dorsal horn of the cat following noxious cutaneous stimulation. Studies with antibody microprobes. Neurosci 35:195-202

Ebrahimi SA, Zareie MR, Rostami P, Mahmoudian M (2003) Interaction of noscapine with the bradykinin mediation of the cough response. Acta Physiol Hung 90:147-155

Eccles R (1996) Codeine, cough and upper respiratory infection. Pulm Pharmacol 9:293-297

El-Hashim AZ, Wyss D, Lewis C (2004) Effect of a novel NK1 receptor selective antagonist (NKP608) on citric acid induced cough and airway obstruction. Pulm Pharmacol Ther 17: $11-18$

Emmerson PJ, Miller RJ (1999) Pre- and postsynaptic actions of opioid and orphan opioid agonists in the rat arcuate nucleus and ventromedial hypothalamus in vitro. J Physiol 517(Part 2): $431-445$

Empey DW, Laitinen LA, Jacobs L, Gold WM, Nadel JA (1976) Mechanisms of bronchial hyperreactivity in normal subjects after upper respiratory tract infection. Am Rev Respir Dis 113:131-139

Empey DW, Laitinen LA, Young GA, Bye CE, Hughes DT (1979) Comparison of the antitussive effects of codeine phosphate $20 \mathrm{mg}$, dextromethorphan $30 \mathrm{mg}$ and noscapine $30 \mathrm{mg}$ using citric acid-induced cough in normal subjects. Eur J Clin Pharmacol 16:393-397

Fahy JV, Wong HH, Geppetti P, Reis JM, Harris SC, Maclean DB, Nadel JA, Boushey HA (1995) Effect of an NK1 receptor antagonist (CP-99,994) on hypertonic saline-induced bronchoconstriction and cough in male asthmatic subjects. Am J Respir Crit Care Med 152:879-884

Featherstone RL, Parry JE, Church MK (1996) The effects of a kinin antagonist on changes in lung function and plasma extravasation into the airways following challenge of sensitized guineapigs. Clin Exp Allergy 26:235-240

Fischer A, Hoffmann B (1996) Nitric oxide synthase in neurons and nerve fibers of lower airways and in vagal sensory ganglia of man. Correlation with neuropeptides. Am J Respir Crit Care Med 154:209-216

Fischer A, Forssmann WG, Undem BJ (1998) Nociceptin-induced inhibition of tachykinergic neurotransmission in guinea pig bronchus. J Pharmacol Exp Ther 285:902-907

Foresi A, Cavigioli G, Pelucchi A, Mastropasqua B, Marazzini L (1996) Effect of acetazolamide on cough induced by low-chloride-ion solutions in normal subjects: Comparison with furosemide. J Allergy Clin Immunol 97:1093-1099

Forsberg K, Karlsson JA, Theodorsson E, Lundberg JM, Persson CG (1988) Cough and bronchoconstriction mediated by capsaicin-sensitive sensory neurons in the guinea-pig. Pulm Pharmacol 1:33-39

Fortin G, Champagnat J (1993) Spontaneous synaptic activities in rat nucleus tractus solitarius neurons in vitro: Evidence for re-excitatory processing. Brain Res 630:125-135

Fox AJ, Barnes PJ, Venkatesan P, Belvisi MG (1997) Activation of large conductance potassium channels inhibits the afferent and efferent function of airway sensory nerves in the guinea pig. J Clin Invest 99:513-519

Franklin PH, Murray TF (1992) High affinity [3H]dextrorphan binding in rat brain is localized to a noncompetitive antagonist site of the activated N-methyl-D-aspartate receptor-cation channel. Mol Pharmacol 41:134-146

Freiman I, Szabo B (2005) Cannabinoids depress excitatory neurotransmission between the subthalamic nucleus and the globus pallidus. Neurosci 133:305-313

French CL, Irwin RS, Curley FJ, Krikorian CJ (1998) Impact of chronic cough on quality of life. Arch Intern Med 158:1657-1661

French CT, Fletcher KE, Irwin RS (2004) Gender differences in health-related quality of life in patients complaining of chronic cough. Chest 125:482-488

French CT, Fletcher KE, Irwin RS (2005) A comparison of gender differences in health-related quality of life in acute and chronic coughers. Chest 127:1991-1998 
Fujimura M, Kamio Y, Hashimoto T, Matsuda T (1996) Effect of capsaicin inhalation on methacholine responsiveness in normal subjects. Clin Auton Res 6:45-48

Fujimura M, Kamio Y, Myou S, Hashimoto T (2000) Effect of oral mexiletine on the cough response to capsaicin and tartaric acid. Thorax 55:126-128

Fuller RW, Collier JG (1984) Sodium cromoglycate and atropine block the fall in FEV1 but not the cough induced by hypotonic mist. Thorax 39:766-770

Fuller RW, Jackson DM (1990) Physiology and treatment of cough. Thorax 45:425-430

Fuller RW, Karlsson JA, Choudry NB, Pride NB (1988) Effect of inhaled and systemic opiates on responses to inhaled capsaicin in humans. J Appl Physiol 65:1125-1130

Gao X, Kim HK, Chung JM, Chung K (2005) Enhancement of NMDA receptor phosphorylation of the spinal dorsal horn and nucleus gracilis neurons in neuropathic rats. Pain 116:62-72

Gastpar H, Criscuolo D, Dieterich HA (1984) Efficacy and tolerability of glaucine as an antitussive agent. Curr Med Res Opin 9:21-27

Giardina GA, Sarau HM, Farina C, Medhurst AD, Grugni M, Foley JJ, Raveglia LF, Schmidt DB, Rigolio R, Vassallo M, Vecchietti V, Hay DW (1996) 2-Phenyl-4-quinolinecarboxamides: A novel class of potent and selective non-peptide competitive antagonists for the human neurokinin-3 receptor. J Med Chem 39:2281-2284

Girard V, Naline E, Vilain P, Emonds-Alt X, Advenier C (1995) Effect of the two tachykinin antagonists, SR 48968 and SR 140333, on cough induced by citric acid in the unanaesthetized guinea pig. Eur Respir J 8:1110-1114

Glatzer NR, Smith BN (2005) Modulation of synaptic transmission in the rat nucleus of the solitary tract by endomorphin-1. J Neurophysiol 93:2530-2540

Gordon R, Gordon RJ, Sofia D (1976) Antitussive activity of some naturally occurring cannabinoids in anesthetized cats. Eur J Pharmacol 35:309-313

Grattan TJ, Marshall AE, Higgins KS, Morice AH (1995) The effect of inhaled and oral dextromethorphan on citric acid induced cough in man. Br J Clin Pharmacol 39:261-263

Groneberg DA, Niimi A, Dinh QT, Cosio B, Hew M, Fischer A, Chung KF (2004) Increased expression of transient receptor potential vanilloid-1 in airway nerves of chronic cough. Am J Respir Crit Care Med 170:1276-1280

Gross PM, Wall KM, Pang JJ, Shaver SW, Wainman DS (1990) Microvascular specializations promoting rapid interstitial solute dispersion in nucleus tractus solitarius. Am J Physiol 259:R1131-R1138

Guitart X, Codony X, Monroy X (2004) Sigma receptors: Biology and therapeutic potential. Psychopharmacology (Berl) 174:301-319

Guo W, Zou S, Guan Y, Ikeda T, Tal M, Dubner R, Ren K (2002) Tyrosine phosphorylation of the NR2B subunit of the NMDA receptor in the spinal cord during the development and maintenance of inflammatory hyperalgesia. J Neurosci 22:6208-6217

Hansson L, Midgren B, Karlsson JA (1994) Effects of inhaled lignocaine and adrenaline on capsaicin- induced cough in humans. Thorax 49:1166-1168

Hargreaves MR, Benson MK (1995) Inhaled sodium cromoglycate in angiotensin-converting enzyme inhibitor cough. Lancet 345:13-16

Hathaway TJ, Higenbottam TW, Morrison JF, Clelland CA, Wallwork J (1993) Effects of inhaled capsaicin in heart-lung transplant patients and asthmatic subjects. Am Rev Respir Dis 148:1233-1237

Hay DW, Giardina GA, Griswold DE, Underwood DC, Kotzer CJ, Bush B, Potts W, Sandhu P, Lundberg D, Foley JJ, Schmidt DB, Martin LD, Kilian D, Legos JJ, Barone FC, Luttmann MA, Grugni M, Raveglia LF, Sarau HM (2002) Nonpeptide tachykinin receptor antagonists. III. SB 235375, a low central nervous system-penetrant, potent and selective neurokinin-3 receptor antagonist, inhibits citric acid-induced cough and airways hyper-reactivity in guinea pigs. J Pharmacol Exp Ther 300:314-323

Herbert ME, Brewster GS (2000) Myth: Codeine is an effective cough suppressant for upper respiratory tract infections. West J Med 173:283

Higenbottam TW (1987) Anticholinergics and cough. Postgrad Med J 63(Suppl 1):75-78 
Hill R (2000) NK1 (substance P) receptor antagonists - why are they not analgesic in humans? Trends Pharmacol Sci 21:244-246

Holmes PW, Barter CE, Pierce RJ (1992) Chronic persistent cough: Use of ipratropium bromide in undiagnosed cases following upper respiratory tract infection. Respir Med 86:425-429

Hope-Gill BD, Hilldrup S, Davies C, Newton RP, Harrison NK (2003) A study of the cough reflex in idiopathic pulmonary fibrosis. Am J Respir Crit Care Med 168:995-1002

Huang SM, Bisogno T, Trevisani M, Al-Hayani A, De PL, Fezza F, Tognetto M, Petros TJ, Krey JF, Chu CJ, Miller JD, Davies SN, Geppetti P, Walker JM, Di Marzo V (2002) An endogenous capsaicin-like substance with high potency at recombinant and native vanilloid VR1 receptors. Proc Natl Acad Sci USA 99:8400-8405

Hunter DD, Undem BJ (1999) Identification and substance P content of vagal afferent neurons innervating the epithelium of the guinea pig trachea. Am J Respir Crit Care Med 159: 1943-1948

Hwang SW, Cho H, Kwak J, Lee SY, Kang CJ, Jung J, Cho S, Min KH, Suh YG, Kim D, Oh U (2000) Direct activation of capsaicin receptors by products of lipoxygenases: Endogenous capsaicin-like substances. Proc Natl Acad Sci USA 97:6155-6160

Irwin RS (2006) Assessing cough severity and efficacy of therapy in clinical research: ACCP evidence-based clinical practice guidelines. Chest 129:232S-237S

Ishiura Y, Fujimura M, Yamamori C, Nobata K, Myou S, Kurashima K, Michishita Y, Takegoshi T (2003) Effect of carbocysteine on cough reflex to capsaicin in asthmatic patients. Br J Clin Pharmacol 55:504-510

Ji RR, Woolf CJ (2001) Neuronal plasticity and signal transduction in nociceptive neurons: Implications for the initiation and maintenance of pathological pain. Neurobiol Dis 8:1-10

Ji RR, Baba H, Brenner GJ, Woolf CJ (1999) Nociceptive-specific activation of ERK in spinal neurons contributes to pain hypersensitivity. Nat Neurosci 2:1114-1119

Ji RR, Kohno T, Moore KA, Woolf CJ (2003) Central sensitization and LTP: Do pain and memory share similar mechanisms? Trends Neurosci 26:696-705

Jia Y, Wang X, Aponte SI, Rivelli MA, Yang R, Rizzo CA, Corboz MR, Priestley T, Hey JA (2002) Nociceptin/orphanin FQ inhibits capsaicin-induced guinea-pig airway contraction through an inward-rectifier potassium channel. Br J Pharmacol 135:764-770

Joos GF, De Swert KO, Schelfhout V, Pauwels RA (2003) The role of neural inflammation in asthma and chronic obstructive pulmonary disease. Ann N Y Acad Sci 992:218-230

Jordan D (2001) Central nervous pathways and control of the airways. Respir Physiol 125:67-81

Kagaya M, Lamb J, Robbins J, Page CP, Spina D (2002) Characterization of the anandamide induced depolarization of guinea-pig isolated vagus nerve. Br J Pharmacol 137:39-48

Kamei J (1996) Role of opioidergic and serotonergic mechanisms in cough and antitussives. Pulm Pharmacol 9:349-356

Kamei J (2002) Delta-opioid receptor antagonists as a new concept for central acting antitussive drugs. Pulm Pharmacol Ther 15:235-240

Karlsson JA (1996) The role of capsaicin-sensitive C-fibre afferent nerves in the cough reflex. Pulm Pharmacol 9:315-321

Karlsson JA, Fuller RW (1999) Pharmacological regulation of the cough reflex-from experimental models to antitussive effects in Man. Pulm Pharmacol Ther 12:215-228

Karlsson JA, Choudry NB, Zackrisson C, Fuller RW (1992) A comparison of the effect of inhaled diuretics on airway reflexes in humans and guinea pigs. J Appl Physiol 72:434-438

Karttunen P, Tukiainen H, Silvasti M, Kolonen S (1987) Antitussive effect of dextromethorphan and dextromethorphan-salbutamol combination in healthy volunteers with artificially induced cough. Respiration 52:49-53

Kato F, Shigetomi E (2001) Distinct modulation of evoked and spontaneous EPSCs by purinoceptors in the nucleus tractus solitarii of the rat. J Physiol 530:469-486

Kohrogi H, Nadel JA, Malfroy B, Gorman C, Bridenbaugh R, Patton JS, Borson DB (1989) Recombinant human enkephalinase (neutral endopeptidase) prevents cough induced by tachykinins in awake guinea pigs. J Clin Invest 84:781-786

Kollarik M, Ru F, Undem BJ (2007) Acid-sensitive vagal sensory pathways and cough. Pulm Pharmacol Ther 20:402-411 
Kopriva F, Sobolova L, Szotkowska J, Zapalka M (2004) Treatment of chronic cough in children with montelukast,a leukotriene receptor antagonist. J Asthma 41:715-720

Kvale PA (2006) Chronic cough due to lung tumors: ACCP evidence-based clinical practice guidelines. Chest 129:147S-153S

Kwong K, Lee LY (2005) Prostaglandin E2 potentiates a TTX-resistant sodium current in rat capsaicin-sensitive vagal pulmonary sensory neurones. J Physiol 564:437-450

Lai J, Porreca F, Hunter JC, Gold MS (2004) Voltage-gated sodium channels and hyperalgesia. Annu Rev Pharmacol Toxicol 44:371-397

Lalloo UG, Fox AJ, Belvisi MG, Chung KF, Barnes PJ (1995) Capsazepine inhibits cough induced by capsaicin and citric acid but not by hypertonic saline in guinea pigs. J Appl Physiol 79: 1082-1087

Laude EA, Morice AH, Grattan TJ (1994) The antitussive effects of menthol, camphor and cineole in conscious guinea-pigs. Pulm Pharmacol 7:179-184

Laursen LC, Lindqvist A, Hepburn T, Lloyd J, Perrett J, Sanders N, Rocchiccioli K (2003) The role of the novel D2/beta2-agonist, Viozan (sibenadet $\mathrm{HCl}$ ), in the treatment of symptoms of chronic obstructive pulmonary disease: Results of a large-scale clinical investigation. Respir Med 97(Suppl A):S23-S33

Lee PCL, Jawad MS, Eccles R (2000) Antitussive efficacy of dextromethorphan in cough associated with acute upper respiratory tract infection. J Pharm Pharmacol 52:1137-1142

Lee J, Lee J, Szabo T, Gonzalez AF, Welter JD, Blumberg PM (2001) N-(3-acyloxy-2benzylpropyl)-N'-dihydroxytetrahydrobenzazepine and tetrahydroisoquinoline thiourea analogues as vanilloid receptor ligands. Bioorg Med Chem 9:1713-1720

Lee SY, Kim MK, Shin C, Shim JJ, Kim HK, Kang KH, Yoo SH, In KH (2003) Substance Pimmunoreactive nerves in endobronchial biopsies in cough-variant asthma and classic asthma. Respiration 70:49-53

Lee J, Alrubaian J, Dores RM (2006) Are lungfish living fossils? Observation on the evolution of the opioid/orphanin gene family. Gen Comp Endocrinol 148:306-314

Lewis CA, Ambrose C, Banner K, Battram C, Butler K, Giddings J, Mok J, Nasra J, Winny C, Poll C (2007) Animal models of cough: Literature review and presentation of a novel cigarette smoke-enhanced cough model in the guinea-pig. Pulm Pharmacol Ther 20:325-333

Lilienfield LS, Rose JC, Princiotto JV (1976) Antitussive activity of diphenhydramine in chronic cough. Clin Pharmacol Ther 19:421-425

Lowry R, Higenbottam T, Johnson T, Godden D (1987) Inhibition of artificially induced cough in man by bronchodilators. Br J Clin Pharmacol 24:503-510

Lundberg JM, Hokfelt T, Martling CR, Saria A, Cuello C (1984) Substance P-immunoreactive sensory nerves in the lower respiratory tract of various mammals including man. Cell Tissue Res 235:251-261

Macpherson LJ, Dubin AE, Evans MJ, Marr F, Schultz PG, Cravatt BF, Patapoutian A (2007) Noxious compounds activate TRPA1 ion channels through covalent modification of cysteines. Nature 445:541-545

Mailleux P, Vanderhaeghen JJ (1992) Distribution of neuronal cannabinoid receptor in the adult rat brain: A comparative receptor binding radioautography and in situ hybridization histochemistry. Neuroscience 48:655-668

Malcangio M, Lessmann V (2003) A common thread for pain and memory synapses? Brainderived neurotrophic factor and trkB receptors. Trends Pharmacol Sci 24:116-121

Mazzone SB (2005) An overview of the sensory receptors regulating cough. Cough 1:2-11

Mazzone SB, McGovern AE (2006) $\mathrm{Na}^{+}-\mathrm{K}^{+}-2 \mathrm{Cl}^{-}$cotransporters and $\mathrm{Cl}^{-}$channels regulate citric acid cough in guinea pigs. J Appl Physiol 101:635-643

Mazzone SB, McGovern AE (2007) Sensory neural targets for the treatment of cough. Clin Exp Pharmacol Physiol 34:955-962

Mazzone SB, Mori N, Canning BJ (2005) Synergistic interactions between airway afferent nerve subtypes regulating the cough reflex in guinea-pigs. J Physiol 569:559-573 
McAlexander MA, Myers AC, Undem BJ (1998) Inhibition of 5-lipoxygenase diminishes neurally evoked tachykinergic contraction of guinea pig isolated airway. J Pharmacol Exp Ther 285:602-607

McGarvey LP, Morice AH (2006) Clinical cough and its mechanisms. Respir Physiol Neurobiol 152:363-371

McKemy DD, Neuhausser WM, Julius D (2002) Identification of a cold receptor reveals a general role for TRP channels in thermosensation. Nature 416:52-58

McLeod RL, Bolser DC, Jia Y, Parra LE, Mutter JC, Wang X, Tulshian DB, Egan RW, Hey JA (2002) Antitussive effect of nociceptin/orphanin FQ in experimental cough models. Pulm Pharmacol Ther 15:213-216

McLeod RL, Jia Y, Fernandez X, Parra LE, Wang X, Tulshian DB, Kiselgof EJ, Tan Z, Fawzi AB, Smith-Torhan A, Zhang H, Hey JA (2004) Antitussive profile of the NOP agonist Ro-64-6198 in the guinea pig. Pharmacology 71:143-149

McLeod RL, Fernandez X, Correll CC, Phelps TP, Jia Y, Wang X, Hey JA (2006) TRPV1 antagonists attenuate antigen-provoked cough in ovalbumin sensitized guinea pigs. Cough 2:10

Meis S, Pape HC (2001) Control of glutamate and GABA release by nociceptin/orphanin FQ in the rat lateral amygdala. J Physiol 532:701-712

Melis M, Pistis M, Perra S, Muntoni AL, Pillolla G, Gessa GL (2004) Endocannabinoids mediate presynaptic inhibition of glutamatergic transmission in rat ventral tegmental area dopamine neurons through activation of CB1 receptors. J Neurosci 24:53-62

Melzack R, Coderre TJ, Katz J, Vaccarino AL (2001) Central neuroplasticity and pathological pain. Ann N Y Acad Sci 933:157-174

Meunier JC, Mollereau C, Toll L, Suaudeau C, Moisand C, Alvinerie P, Butour JL, Guillemot JC, Ferrara P, Monsarrat B, Mazarguil H, Vassart G, Parmentier M, Costentin J (1995) Isolation and structure of the endogenous agonist of opioid receptor-like $\mathrm{ORL}_{1}$ receptor. Nature 377:532-535

Midgren B, Hansson L, Karlsson JA, Simonsson BG, Persson CG (1992) Capsaicin-induced cough in humans. Am Rev Respir Dis 146:347-351

Mifflin SW, Felder RB (1990) Synaptic mechanisms regulating cardiovascular afferent inputs to solitary tract nucleus. Am J Physiol 259:H653-H661

Mochizuki H, Shimizu T, Morikawa A, Kuroume T (1995) Inhaled diuretics attenuate acid-induced cough in children with asthma. Chest 107:413-417

Monnet FP (2005) Sigma-1 receptor as regulator of neuronal intracellular Ca2+: Clinical and therapeutic relevance. Biol Cell 97:873-883

Monteillet-Agius G, Fein J, Anton B, Evans CJ (1998) ORL-1 and mu opioid receptor antisera label different fibers in areas involved in pain processing. J Comp Neurol 399:373-383

Mooraki A, Jenabi A, Jabbari M, Zolfaghari MI, Javanmardi SZ, Mahmoudian M, Bastani B (2005) Noscapine suppresses angiotensin converting enzyme inhibitors-induced cough. Nephrology (Carlton) 10:348-350

Moreaux B, Nemmar A, Vincke G, Halloy D, Beerens D, Advenier C, Gustin P (2000) Role of substance $\mathrm{P}$ and tachykinin receptor antagonists in citric acid-induced cough in pigs. Eur $\mathrm{J}$ Pharmacol 408:305-312

Morice AH, Geppetti P (2004) Cough. 5: The type 1 vanilloid receptor: a sensory receptor for cough. Thorax 59:257-258

Morice AH, Lowry R, Brown MJ, Higenbottam T (1987) Angiotensin-converting enzyme and the cough reflex. Lancet 2:1116-1118

Morice AH, Marshall AE, Higgins KS, Grattan TJ (1994) Effect of inhaled menthol on citric acid induced cough in normal subjects. Thorax 49:1024-1026

Morice AH, Fontana GA, Sovijarvi AR, Pistolesi M, Chung KF, Widdicombe JG, O'Connell F, Geppetti P, Gronke L, De JJ, Belvisi M, Dicpinigaitis P, Fischer A, McGarvey L, Fokkens WJ, Kastelik J (2004) The diagnosis and management of chronic cough. Eur Respir J 24:481-492

Morice AH, Menon MS, Mulrennan SA, Everett CF, Wright C, Jackson J, Thompson R (2007) Opiate therapy in chronic cough. Am J Respir Crit Care Med 175:312-315

Mulrennan S, Wright C, Thompson R, Goustas P, Morice A (2004) Effect of salbutamol on smoking related cough. Pulm Pharmacol Ther 17:127-131 
Mutoh T, Bonham AC, Kott KS, Joad JP (1999) Chronic exposure to sidestream tobacco smoke augments lung C-fiber responsiveness in young guinea pigs. J Appl Physiol 87:757-768

Mutoh T, Joad JP, Bonham AC (2000) Chronic passive cigarette smoke exposure augments bronchopulmonary C-fibre inputs to nucleus tractus solitarii neurones and reflex output in young guinea-pigs. J Physiol 523(Part 1):223-233

Myers AC, Kajekar R, Undem BJ (2002) Allergic inflammation-induced neuropeptide production in rapidly adapting afferent nerves in guinea pig airways. Am J Physiol Lung Cell Mol Physiol 282:L775-L781

Nakajima T, Nishimura Y, Nishiuma T, Kotani Y, Nakata H, Yokoyama M (2006) Cough sensitivity in pure cough variant asthma elicited using continuous capsaicin inhalation. Allergol Int 55:149-155

Netzer R, Pflimlin P, Trube G (1993) Dextromethorphan blocks N-methyl-D-aspartate-induced currents and voltage-operated inward currents in cultured cortical neurons. Eur J Pharmacol 238:209-216

Nichol GM, Alton EW, Nix A, Geddes DM, Chung KF, Barnes PJ (1990) Effect of inhaled furosemide on metabisulfite- and methacholine-induced bronchoconstriction and nasal potential difference in asthmatic subjects. Am Rev Respir Dis 142:576-580

Nilius B, Owsianik G, Voets T, Peters JA (2007) Transient receptor potential cation channels in disease. Physiol Rev 87:165-217

O'Connell F, Thomas VE, Pride NB, Fuller RW (1994) Capsaicin cough sensitivity decreases with successful treatment of chronic cough. Am J Respir Crit Care Med 150:374-380

O'Connell F, Springall DR, Moradoghli-Haftvani A, Krausz T, Price D, Fuller RW, Polak JM, Pride NB (1995) Abnormal intraepithelial airway nerves in persistent unexplained cough? Am J Respir Crit Care Med 152:2068-2075

O'Connell F, Thomas VE, Studham JM, Pride NB, Fuller RW (1996) Capsaicin cough sensitivity increases during upper respiratory infection. Respir Med 90:279-286

Pacher P, Batkai S, Kunos G (2006) The endocannabinoid system as an emerging target of pharmacotherapy. Pharmacol Rev 58:389-462

Packman EW, Ciccone PE, Wilson J, Masurat T (1991) Antitussive effects of diphenhydramine on the citric acid aerosol-induced cough response in humans. Int J Clin Pharmacol Ther Toxicol 29:218-222

Pantaleo T, Bongianni F, Mutolo D (2002) Central nervous mechanisms of cough. Pulm Pharmacol Ther 15:227-233

Park KA, Vasko MR (2005) Lipid mediators of sensitivity in sensory neurons. Trends Pharmacol Sci 26:571-577

Patel HJ, Birrell MA, Crispino N, Hele DJ, Venkatesan P, Barnes PJ, Yacoub MH, Belvisi MG (2003) Inhibition of guinea-pig and human sensory nerve activity and the cough reflex in guinea-pigs by cannabinoid (CB2) receptor activation. Br J Pharmacol 140:261-268

Pavord I, Hall I, Wahedna I, Cooper S, Tattersfield A (1994) Effect of 443c81, an inhaled mu-opioid receptor agonist in asthma. Clin Exp Allergy 24:144-148

Pezet S, Spyropoulos A, Williams RJ, McMahon SB (2005) Activity-dependent phosphorylation of Akt/PKB in adult DRG neurons. Eur J Neurosci 21:1785-1797

Pillay V, Swingler G (2003) Symptomatic treatment of the cough in whooping cough. Cochrane Database Syst Rev:CD003257

Pounsford JC, Birch MJ, Saunders KB (1985) Effect of bronchodilators on the cough response to inhaled citric acid in normal and asthmatic subjects. Thorax 40:662-667

Pratter MR (2006) Cough and the common cold: ACCP evidence-based clinical practice guidelines. Chest 129:72S-74S

Pratter MR, Brightling CE, Boulet LP, Irwin RS (2006) An empiric integrative approach to the management of cough: ACCP evidence-based clinical practice guidelines. Chest 129: 222S-231S

Rees PJ, Clark TJ (1983) Assessment of antitussive effects by citric acid threshold. Br J Dis Chest 77:94-97 
Reynolds SM, Mackenzie AJ, Spina D, Page CP (2004) The pharmacology of cough. Trends Pharmacol Sci 25:569-576

Riccio MM, Myers AC, Undem BJ (1996) Immunomodulation of afferent neurones in guinea-pig isolated airways. J Physiol 491:499-509

Ruhle KH, Criscuolo D, Dieterich HA, Kohler D, Riedel G (1984) Objective evaluation of dextromethorphan and glaucine as antitussive agents. Br J Clin Pharmacol 17:521-524

Sant'Ambrogio FB, Sant'Ambrogio G, Anderson JW (1993) Effect of furosemide on the response of laryngeal receptors to low-chloride solutions. Eur Respir J 6:1151-1155

Schroeder K, Fahey T (2002) Systematic review of randomised controlled trials of over the counter cough medicines for acute cough in adults. Br Med J 324:329-331

Schroeder K, Fahey T (2004) Over-the-counter medications for acute cough in children and adults in ambulatory settings. Cochrane Database Syst Rev:CD001831

Sekizawa K, Jia YX, Ebihara T, Hirose Y, Hirayama Y, Sasaki H (1996) Role of substance P in cough. Pulm Pharmacol 9:323-328

Sekizawa S, Joad JP, Bonham AC (2003) Substance P presynaptically depresses the transmission of sensory input to bronchopulmonary neurons in the guinea pig nucleus tractus solitarii. J Physiol 552:547-559

Shah S, Page CP, Spina D (1998) Nociceptin inhibits non-adrenergic non-cholinergic contraction in guinea-pig airway. Br J Pharmacol 125:510-516

Shannon R, Baekey DM, Morris KF, Li Z, Lindsey BG (2000) Functional connectivity among ventrolateral medullary respiratory neurones and responses during fictive cough in the cat. $\mathrm{J}$ Physiol 525(Part 1):207-224

Sheppard D, Rizk NW, Boushey HA, Bethel RA (1983) Mechanism of cough and bronchoconstriction induced by distilled water aerosol. Am Rev Respir Dis 127:691-694

Shin J, Cho H, Hwang SW, Jung J, Shin CY, Lee SY, Kim SH, Lee MG, Choi YH, Kim J, Haber NA, Reichling DB, Khasar S, Levine JD, Oh U (2002) Bradykinin-12-lipoxygenaseVR1 signaling pathway for inflammatory hyperalgesia. Proc Natl Acad Sci USA 99:1015010155

Smart D, Gunthorpe MJ, Jerman JC, Nasir S, Gray J, Muir AI, Chambers JK, Randall AD, Davis JB (2000) The endogenous lipid anandamide is a full agonist at the human vanilloid receptor (hVR1). Br J Pharmacol 129:227-230

Smith CA, Adamson DL, Choudry NB, Fuller RW (1991) The effect of altering airway tone on the sensitivity of the cough reflex in normal volunteers. Eur Respir J 4:1078-1079

Smith BN, Dou P, Barber WD, Dudek FE (1998) Vagally evoked synaptic currents in the immature rat nucleus tractus solitarii in an intact in vitro preparation. J Physiol 512(Part 1):149-162

Soya A, Serino R, Fujihara H, Onaka T, Ozaki Y, Saito T, Nakamura J, Ueta Y (2005) Cannabinoids modulate synaptic activity in the rat supraoptic nucleus. J Neuroendocrinol 17:609-615

Spina D, Page CP, Morley J. (1998). Sensory neuropeptides and bronchial hyperresponsiveness.In: Said SI (ed) ProInflammatory and antiinflammatory peptides. Marcel Deckker, New York, pp 89-146

Stone RA, Barnes PJ, Chung KF (1993a) Effect of frusemide on cough responses to chloridedeficient solution in normal and mild asthmatic subjects. Eur Respir J 6:862-867

Stone RA, Worsdell YM, Fuller RW, Barnes PJ (1993b) Effects of 5-hydroxytryptamine and 5hydroxytryptophan infusion on the human cough reflex. J Appl Physiol 74:396-401

Studham J, Fuller RW (1992) The effect of oral terfenadine on the sensitivity of the cough reflex in normal volunteers. Pulm Pharmacol 5:51-52

Suzuki K, Sato M, Morishima Y, Nakanishi S (2005) Neuronal depolarization controls brainderived neurotrophic factor-induced upregulation of NR2C NMDA receptor via calcineurin signaling. J Neurosci 25:9535-9543

Szallasi A, Blumberg PM (1999) Vanilloid (Capsaicin) receptors and mechanisms. Pharmacol Rev 51:159-211

Tashkin DP, Reiss S, Shapiro BJ, Calvarese B, Olsen JL, Lodge JW (1977) Bronchial effects of aerosolized delta 9-tetrahydrocannabinol in healthy and asthmatic subjects. Am Rev Respir Dis 115:57-65 
Tatar M, Webber SE, Widdicombe JG (1988) Lung C-fibre receptor activation and defensive reflexes in anaesthetized cats. J Physiol 402:411-420

Tatar M, Sant'Ambrogio G, Sant'Ambrogio FB (1994) Laryngeal and tracheobronchial cough in anesthetized dogs. J Appl Physiol 76:2672-2679

Trevisani M, Milan A, Gatti R, Zanasi A, Harrison S, Fontana G, Morice AH, Geppetti P (2004) Antitussive activity of iodo-resiniferatoxin in guinea pigs. Thorax 59:769-772

Trochtenberg S (1994) Nebulized lidocaine in the treatment of refractory cough. Chest 105: $1592-1593$

Tucker RC, Kagaya M, Page CP, Spina D (2001) The endogenous cannabinoid agonist, anandamide stimulates sensory nerves in guinea-pig airways. Br J Pharmacol 132:1127-1135

Undem BJ, Weinreich D (1993) Electrophysiological properties and chemosensitivity of guinea pig nodose ganglion neurons in vitro. J Auton Nerv Syst 44:17-33

Undem BJ, Carr MJ, Kollarik M (2002) Physiology and plasticity of putative cough fibres in the Guinea pig. Pulm Pharmacol Ther 15:193-198

Ventresca PG, Nichol GM, Barnes PJ, Chung KF (1990) Inhaled furosemide inhibits cough induced by low chloride content solutions but not by capsaicin. Am Rev Respir Dis 142:143-146

Wang L, Bradley RM (1995) In vitro study of afferent synaptic transmission in the rostral gustatory zone of the rat nucleus of the solitary tract. Brain Res 702:188-198

Watanabe N, Horie S, Michael GJ, Spina D, Page CP, Priestley JV (2005) Immunohistochemical localization of vanilloid receptor subtype 1 (TRPV1) in the guinea pig respiratory system. Pulm Pharmacol Ther 18:187-197

Watanabe N, Horie S, Michael GJ, Keir S, Spina D, Page CP, Priestley JV (2006) Immunohistochemical co-localization of transient receptor potential vanilloid (TRPV) 1 and sensory neuropeptides in the guinea-pig respiratory system. Neuroscience 141:1533-1543

Weinfeld D, Ternesten-Hasseus E, Lowhagen O, Millqvist E (2002) Capsaicin cough sensitivity in allergic asthmatic patients increases during the birch pollen season. Ann Allergy Asthma Immunol 89:419-424

Widdicombe JG (1995) Neurophysiology of the cough reflex. Eur Respir J 8:1193-1202

Widdicombe JG (2003) Overview of neural pathways in allergy and asthma. Pulm Pharmacol Ther $16: 23-30$

Woolf CJ, King AE (1989) Subthreshold components of the cutaneous mechanoreceptive fields of dorsal horn neurons in the rat lumbar spinal cord. J Neurophysiol 62:907-916

Woolf CJ, King AE (1990) Dynamic alterations in the cutaneous mechanoreceptive fields of dorsal horn neurons in the rat spinal cord. J Neurosci 10:2717-2726

Woolf CJ, Salter MW (2000) Neuronal plasticity: Increasing the gain in pain. Science 288: $1765-1769$

Woolf CJ, Wall PD (1986) Relative effectiveness of C primary afferent fibers of different origins in evoking a prolonged facilitation of the flexor reflex in the rat. J Neurosci 6:1433-1442

Yang L, Zhang FX, Huang F, Lu YJ, Li GD, Bao L, Xiao HS, Zhang X (2004) Peripheral nerve injury induces trans-synaptic modification of channels, receptors and signal pathways in rat dorsal spinal cord. Eur J Neurosci 19:871-883

Yasumitsu R, Hirayama Y, Imai T, Miyayasu K, Hiroi J (1996) Effects of specific tachykinin receptor antagonists on citric acid-induced cough and bronchoconstriction in unanesthetized guinea pigs. Eur J Pharmacol 300:215-219

Yukioka H, Yoshimoto N, Nishimura K, Fujimori M (1985) Intravenous lidocaine as a suppressant of coughing during tracheal intubation. Anesth Analg 64:1189-1192

Zou X, Lin Q, Willis WD (2000) Enhanced phosphorylation of NMDA receptor 1 subunits in spinal cord dorsal horn and spinothalamic tract neurons after intradermal injection of capsaicin in rats. J Neurosci 20:6989-6997

Zygmunt PM, Petersson J, Andersson DA, Chuang HH, Sorgard M, DiMarzo M, Julius V, Hogestatt ED (1999) Vanilloid receptors on sensory nerves mediate the vasodilator action of anandamide. Nature 400:452-457 